\title{
Distant Recombination and the Creation of Basic Inventions An Analysis of the Diffusion of Public and Private Sector Nanotechnology Patents in Canada
}

Barirani, Ahmad; Beaudry, Catherine; Agard, Bruno

Document Version

Accepted author manuscript

Published in:

Technovation

DOI:

10.1016/j.technovation.2014.10.002

Publication date:

2015

License

CC BY-NC-ND

Citation for published version (APA):

Barirani, A., Beaudry, C., \& Agard, B. (2015). Distant Recombination and the Creation of Basic Inventions: An Analysis of the Diffusion of Public and Private Sector Nanotechnology Patents in Canada. Technovation, 3637(February-March), 39-52. https://doi.org/10.1016/j.technovation.2014.10.002

Link to publication in CBS Research Portal

\section{General rights}

Copyright and moral rights for the publications made accessible in the public portal are retained by the authors and/or other copyright owners and it is a condition of accessing publications that users recognise and abide by the legal requirements associated with these rights.

\section{Take down policy}

If you believe that this document breaches copyright please contact us (research.lib@cbs.dk) providing details, and we will remove access to the work immediately and investigate your claim. 


\title{
Distant Recombination and the Creation of Basic Inventions: An Analysis of the Diffusion of Public and Private Sector Nanotechnology Patents in Canada
}

\section{Ahmad Bariani, Cathrine Beaudry, and Bruno Agard}

\author{
Journal article (Post print version)
}

Cite: Distant Recombination and the Creation of Basic Inventions : An Analysis of the Diffusion of Public and Private Sector Nanotechnology Patents in Canada. / Barirani, Ahmad; Beaudry, Catherine; Agard, Bruno. I: Technovation, Vol. 36-37, Nr. FebruaryMarch, २015, s. 39-52.

DOI: http://dx.doi.org/10.1016/j.technovation.2014.10.002

Uploaded to Research@CBS: September २०16

(C) 2016. This manuscript version is made available under the CC-BY-NC-ND 4.0 license http://creativecommons.org/licenses/by-nc-nd/4.0/ 


\title{
Distant recombination and the creation of basic inventions: an analysis of the diffusion of public and private sector nanotechnology patents in Canada
}

\author{
Ahmad Barirani $^{\mathrm{a}}$, Catherine Beaudry ${ }^{\mathrm{a}, \mathrm{b}, *}$, Bruno Agard $^{\mathrm{a}}$ \\ ${ }^{a}$ Ecole Polytechnique of Montreal, P.O. Box. 6079, Downtown Office, Montreal, Qc, H3C 3A7, \\ Canada \\ ${ }^{b}$ Centre for Interuniversity Research on Science and Technology (CIRST), Université du Québec \\ à Montréal, P.O. Box 8888, Downtown Office, Montreal, Qc, H3C 3P8, Canada
}

\begin{abstract}
This article explores whether the relationship between the breath of technological integration (recombination distance) and the breath of an invention's subsequent application (basicness) is moderated by the sector of activity, science-linkage strength and industry characteristics. Our analysis of Canadian nanotechnology patents granted between 1990 and 1997 shows that although private organizations generally yield smaller rates of basic inventions than public organizations, increases to recombination distance by the former increases invention basicness at a higher rate; increasing reliance upon basic science moderates the relationship between recombination distance and basicness; and increases to recombination distance in emerging science-based industries increases invention basicness at a higher rate. These findings have implications regarding the debate around the efficiency of the academic enterprise model.
\end{abstract}

* Corresponding author at: Department of Mathematics and Industrial Engineering, Ecole Polytechnique of Montreal, P.O. Box. 6079, Downtown office, Montreal, Qc, H3C 3A7, Canada. Tel.: +1 514340 4711x3357; fax: +1 514340 4173. E-mail addresses: catherine.beaudry@polymtl.ca 
Keywords: Academic enterprise, Markets for technology, Search heuristics, Capabilities, Knowledge diffusion

\section{Introduction}

Basic inventions have broad technological applications and are the foundations of many subsequent focused inventions whose applications are confined to narrow fields (Trajtenberg et al., 1997). Studies about shifts in the rate of creation of the former type of inventions concurring with the emergence of the academic enterprise have led to a debate about a shift in the nature of academic research (Larsen, 2011).

Henderson et al. (1998) claim that the basicness of university patents seems to be declining with the emergence of the academic enterprise. Based on the observation that recombination distance (the breath of technological integration) is linked to invention basicness (Trajtenberg et al., 1997), the authors conclude that this change in the quality of academic patents could imply a change in the nature of academic research.

A reply to this study comes from Mowery and Ziedonis (2002) who claim that the observed decline can mostly be attributed to entry by inexperienced universities and that learning effects can improve the importance of patents produced by the latter (Mowery et al., 2002). Mowery and Sampat (2005) further stress that university-industry technology transfer has been mostly successful in sciencebased industries such as pharmaceuticals and biotechnology. These observations possibly imply that differences in organizational capabilities and industry characteristics can moderate the relationship between recombination distance and invention basicness. 
On the subject of organizational capabilities, Banerjee and Cole (2010) show that firm entry into new application domains by a sample of biotechnology entrepreneurial firms has a negative moderating effect on the relationship between recombination distance and basicness. Is it then possible that the sector of activity from which an invention originates could also moderate the relationship between recombination distance and basicness? Do other factors related to the universityindustry interface, such as industry characteristics and science-linkage strength of an invention, have similar moderating effects?

To answer the above questions, we will perform an econometric analysis by using a sample of Canadian nanotechnology patents registered in the US. This emerging multidisciplinary field can potentially breed "general purpose technologies" (Youtie et al., 2008; Gómez-Baquero, 2009; Shea et al., 2011) and offers the possibility to study the above-mentioned factors. We measure a patent's recombination distance and invention basicness by constructing a Herfindahl-based index of the diversity of technological classes from its backward and forward citations respectively (Trajtenberg et al., 1997). By mean of regression analysis, we measure the moderating effect that the sector of activity (private or public), strength of science linkage and industry emergence have on the relationship between recombination distance and invention basicness.

In line with findings of Trajtenberg et al. (1997) and Banerjee and Cole (2010), our results show that recombination distance is indeed positively linked with invention basicness. However, we also find that while private organizations are less likely to produce basic inventions, an increase in recombination distance by them increases invention basicness at a higher rate. Science-linkage strength has a negative moderating effect on distant recombination. Finally, our results show that an 
increase in recombination distance increases invention basicness at a higher rate in the fragmented science-based nanotechnology industry. The remainder of this paper is organized as follows: section 2 reviews the literature lists our hypotheses; section 3 provides a complete description of the methodology; section 4 presents the results; and section 5 discusses the results and provides some conclusions.

\section{Literature Review and hypotheses}

\subsection{Measuring innovative activity through patenting}

From a legal point of view, patents confer monopolistic power with regards to the use, production and commercialization of an invention in exchange of its disclosure. Since patents are granted to inventions that are novel, non-obvious and useful, they can generally be viewed as indicators of technological change and innovative activity (Basberg, 1987; Acs and Audretsch, 1989; Griliches, 1990; Archibugi and Pianta, 1996). Various studies, however, point out that the majority of patents have little economic value (Allison et al., 2004; Moore, 2005). Patenting can sometimes be compared to gambling where firms bet on slots (Lemley and Shapiro, 2005). Also, as Pénin (2005) points out, patents can be used as strategic devices and, consequently, cannot be used in a straightforward manner to measure innovation. Nevertheless, some patent quality indicators are known to be associated with commercial success: patent citations can be linked to firm value (Trajtenberg, 1990; Hall et al., 2005) and patents deposed in the US by foreigners have a higher expected value (Bessen, 2008).

Forward citations can be used in various ways to measure patent quality (Squicciarini et al., 2013). One method supposes that important inventions are those that are subsequently used by a great number of inventions. This method typically con- 
sists in counting forward citations of a patent to measure its importance (Fleming, 2001; Sapsalis et al., 2006). Another method considers how the eventual use of an invention spreads over technological classes (Trajtenberg et al., 1997; Henderson et al., 1998; Mowery and Ziedonis, 2002), hence relying on the classification of a patent's forward citations in order to measure invention quality. Patents that are subsequently cited in different technological classes are believed to be more basic. Both basicness and forward citation counts have been associated with patent value (Bessen, 2008; Serrano, 2010; Sreekumaran Nair et al., 2011; Fischer and Leidinger, 2014). Nonetheless, metrics using forward citations can also be viewed as indicators of invention social value (Baron and Delcamp, 2012).

A few precisions are in order regarding patent citations. First, one should note that while applicants have the obligation to cite all related sources of knowledge, they are not legally obliged to perform prior art search. In fact, it is incumbent upon USPTO examiners to make sure that all appropriate sources are cited. Because patents constitute legal documents, examiners go through a thorough search process in which they attempt to add all citations that are relevant to a patent (Trajtenberg, 1990). Because a patent's scope is defined by the novel features of an invention, proper reference to prior art should be made in order to correctly define the technological boundaries legally protected by the patent (Merges and Nelson, 1990). This renders the examination process essential to the preservation of patent scope legal validity.

Based on these premises, Jaffe et al. (1993) argue that patent citations represent knowledge spillovers generated by patents. This assumption has been, to a certain degree, brought into question for two reasons. On the one hand, because citations restrict the patent's scope, applicants often choose not to perform prior art 
search, and when they do, they can cite other patents strategically (Sampat, 2010). On the other hand, variations among patent examiners have been found implying that some patents could contain citations that are more accurate than others (Cockburn et al., 2002; Alcácer and Gittelman, 2006). Also, time constraints can lead examiners to add citations that are only remotely linked to the applied patent in order to make sure that nothing has been missed out (Meyer, 2000). There are reasons, nevertheless, to believe that patent citations contain relevant information that can have analytical value.

A number of studies argue that applicants have more incentives to search for prior art for discrete technologies such as pharmaceuticals or chemicals while the opposite hold for complex technologies such as electronics or telecommunication (Lemley and Shapiro, 2005; Sampat, 2010; Alcácer et al., 2009). Hegde and Sampat (2009) further show that examiner added citations are better predictors of patent renewal than applicant added citations. In addition, examiner citations are more likely to be added when there is technological and geographical distance between citing and cited patent (Criscuolo and Verspagen, 2008). It is also worthwhile to note that examiners add a larger share of self-citations than the inventors themselves (Sampat, 2010; Alcácer et al., 2009). Based on these considerations, patent examination can also be viewed as a smoothing process that can sometimes close citation gaps between related inventions (Azagra-Caro et al., 2011). USPTO citations are indeed generally viewed as thorough in terms of containing links to relevant prior art (Meyer, 2000; Von Wartburg et al., 2005).

Examiner citations can also be interpreted from a social learning perspective (Amin and Cohendet, 2004). Although the validity of using patent citations to measure knowledge flows can be brought into question, it is undeniable that ap- 
plicants must, to a certain degree, be aware of contemporary technological developments before engaging in R\&D activities. Since learning can be viewed as a social process and that technological development is path-dependent (Rosenberg, 1994), it is difficult to imagine that in knowledge intensive industries, inventors can be totally unaware of current technological challenges and potential solutions, and yet be successful in introducing novelties. Being part of the social process of learning, inventors who search for novel solutions are embedded to their community of practice. Furthermore, the tacit dimension of knowledge spillovers implies that they do not always leave traces in the form of citations and do not necessarily require formal transfer of knowledge (Krugman, 1991). Since this embedding is likely to encompass even inventors who are employed by competitors, an applicant's failure to cite a relevant prior art does not necessarily rule out tacit knowledge about related technologies.

\subsection{The emergence of academic enterprise}

Viewed as providers and repositories of basic knowledge, universities have historically taken part in R\&D activities that have low levels of appropriability and in which firms found little incentives to invest (Nelson, 1959; Arrow, 1962). Basic research undertaken by universities had tremendous spillovers to the industry (Jaffe, 1989; Adams, 1990; Zucker and Darby, 1996; Narin et al., 1997; Cohen et al., 2002). The recognition of this phenomenon has led some to consider a greater integration of universities with commercial activities (Etzkowitz, 1998; Jensen and Thursby, 2001), an idea that is not unanimously acclaimed by scholars (Larsen, 2011; Philpott et al., 2011). A major source of debate is about a possible shift of university research toward more applied sciences, leading to an eventual gap in basic research which might not be filled by firms (Foray and Lissoni, 2010). 
An important source of disagreement related to this debate is the concept that public research is coordinated by a reputation-based reward system, and that it is through this non-market mechanism that scientists endeavor risky exploratory research (Dasgupta and David, 1994; Stephan, 1996; David, 2004). Changing the reward system might change the behavior of academia and impact scientific production. Other mechanisms that foster university-industry technology transfer and which do not necessarily have to involve university patenting can be considered (D’Este and Patel, 2007; Yusuf, 2008; Grimpe and Hussinger, 2013). In another line of thought, it is claimed that research groups act as "quasi-firms" when they perform their day-to-day routines (Etzkowitz, 2003). This idea reflects the assumption that entrepreneurial universities can be successful in both performing their duty of "searching for the truth" and transferring technologies to the marketplace (Etzkowitz, 1998). With the emergence of "markets for technology" (Arora et al., 2001; Debackere and Veugelers, 2005), the idea that universities can benefit commercially by supplying technologies to the industry can be reinforced by empirical findings that do not see real differences in the value distribution of academic and industry patents (Sapsalis et al., 2006).

\subsection{Search heuristics, capabilities and the self-organization of inventive activity}

From the perspective of evolutionary economics, inventing can be viewed as the act of combining exiting resources in new ways (Schumpeter, 1934; Nelson and Winter, 1982). Recombination is the result of a "search" process aimed at identifying and selecting useful components to solve problems in a "satisficing" manner (March and Simon, 1958; Cyert and March, 1963). This selection process can be analogous to the evolution of biological species, except it is not blind but rather purposeful in nature (Nelson and Winter, 1982). 
When searching for existing components, agents can resort to a dichotomous set of heuristics: they can either exploit known technological paths or explore new ones (March, 1991). Knowledge exploitation leads to local recombination, i.e. the integration of components situated in the immediate periphery of dominant routines. This option involves the improvement of current procedures and an ever increasing specialization of the firm in a few fields of expertise. Knowledge exploration in contrast involves searching or experimenting in ways that break away from dominant routines. It requires learning radically different ways of solving problems and leads to distant recombination (Gruber et al., 2013).

Empirical findings generally associate the dichotomous nature of these search heuristics to a dichotomy in their outcomes. In line with the idea that distant recombination will yield basic inventions (Trajtenberg et al., 1997), Rosenkopf and Nerkar (2001) show that searching beyond the boundaries of the optical disk industry is more likely to lead to an invention that will be used in other industries. Datta and Jessup (2013) also show that searching outside an industry leads to the development of more radical inventions. Fleming (2001) argues that local recombination contributes to the creation of incremental innovations while distant recombination, although leading to many failures, is more likely to lead to radical innovations. Similarly, Kim et al. (2012) find that exploitative search is positively linked with invention rates but negatively with impact, while exploratory search exhibits the opposite relationships.

Exclusive reliance on one heuristic can be detrimental to organizational capabilities. Although local recombination allows easier absorption of knowledge and lower levels of uncertainty, firms that over-exploit existing routines can be stuck in a competency trap where they cannot effectively adapt to an environment 
dominated by the widespread diffusion of components that are distant from the ones with which they are familiar (Levitt and March, 1988; Levinthal and March, 1993). According to Tushman and O'Reilly III (1996)'s ambidexterity perspective, exploitation increases organizational efficiency and is beneficial in times of environmental stability, while exploration increases organizational flexibility and is beneficial in times of environmental fluctuation. From this perspective, exploration increases a firm's "absorptive capacity" (ability to learn from its environment) and thus to adapt to changing environments (Cohen and Levinthal, 1989, 1990; Raisch et al., 2009).

The aggregate effort of opportunity seeking agents having heterogeneous capabilities can be viewed as a complex adaptive system (Silverberg et al., 1988; Fleming and Sorenson, 2001). In this perspective, inventors evolve in a community which is constantly recombining existing technologies to create new ones. This collective effort results in a complex network of interlinked technological components. In this setting, the search process is partly simplified by the presence of "technological trajectories" which act as "cognitive outposts" shared collectively and direct search effort toward certain paths (Dosi, 1982). "Bounded rationality", however, implies that search is performed without a priori knowledge of its outcome. Even if technological trajectories act as guideposts for search, neither opportunities nor the ways to grasp them are entirely known in advance (Cyert and March, 1963; Dosi, 1988). The diffusion of inventions reflects the heterogeneous learning capabilities of, and the search heuristics employed by, the collection of agents (Dosi, 1988; Geroski, 2000). What is adopted, and deemed useful, is what falls within search. Given that there is always an upper bound on agents' absorptive capacity, the adoption of potentially useful inventions is not 
warranted.

\subsection{Inter-institutional heterogeneity and the public-private dichotomy}

If heterogeneous capabilities at intra-institutional level can explain differences in the quality of academic patents (Mowery et al., 2002; Czarnitzki et al., 2011; Acosta et al., 2012), then the same principle can be applied to expect similar observation at inter-institutional level, i.e. between the private and the public sector.

Institutional proximity between inventive agents can influence the knowledge diffusion process (Cantwell, 2000; Boschma, 2005; D'Amore et al., 2013). This perspective would suggest that organizations are more likely to recombine technologies produced by organizations that are bound to the same rules and norms. Inter-institutional heterogeneity can be rooted in the normative rules and reward systems to which private and public sector are respectively subjected (Dasgupta and David, 1994; Stephan, 1996; Tartari and Breschi, 2012; Bodas Freitas and Nuvolari, 2012; Veer and Jell, 2012; Ankrah et al., 2013). Faced with short-term imperatives, firms often have the reflex of exploiting already possessed skills (Tushman and O'Reilly III, 1996; Ahuja and Lampert, 2001; Fang et al., 2010). Such imperatives are not imposed on public organizations that do not abide to market norms. While this reality can have an impact on the respective capabilities of private and public sector organizations to perform basic research (Trajtenberg et al., 1997), it can also have an impact on how easily inventions produced by the public sector pervade across institutional boundaries and be adopted in the private sector.

In other words, institutional proximity between actors in the private sector directs technological development towards trajectory commonly adhered by actors in that sector. The more complex is an invention, and thus its absorption 
difficult, the more difficult becomes inter-institutional transfer (Petruzzelli, 2011; Czarnitzki et al., 2012; Woerter, 2012; Muscio and Pozzali, 2013). In a technological landscape where most patents are owned by the private sector, the picture could appear grim for the diffusion of complex inventions resulting from public sector research. Popular views about the embryonic nature of university inventions, whether true or not (Jensen and Thursby, 2001; Colyvas et al., 2002), could create a bias which would advantage the diffusion of private sector inventions that result from distant recombination.

Another source of inter-institutional heterogeneity can be traced in the respective complementary assets (Teece, 1986) owned by the private and the public sector. Here, one major difference is that patent licensing consists in the main channel for technology commercialization that public organizations dispose of (Shane, 2004b). Even though spinoffs can theoretically be created around university technologies, they represent a small percentage of invention disclosures (Shane, 2004a). In other words, strategic options for public organizations are limited to the markets for technologies.

While it is true that markets for technology offer new strategic possibilities, their presence alone does not guarantee the diffusion of technologies. While complementary assets are not required for entering the markets for technology, it does not mean that they are not useful for proper screening and sensing of technological opportunities (Day, 1994; Teece, 1998, 2007).

Here, a relevant feature of complementary assets could be noted in $R \& D$ and marketing integration (Griffin and Hauser, 1996; Leenders and Wierenga, 2002; Verhoef and Leeflang, 2009). Given that R\&D and marketing integration activities can be seen as central components to foresight and sensing (Day, 1994), this factor 
can also contribute to different outcomes with regards to distant recombination. Indeed, such capabilities can embed market knowledge during the search process and allow for recombinations that will land on the right outposts of technological trajectories. Regarding R\&D and marketing integration, it is difficult to claim that public sector organizations have the same kind of capabilities than those in the private sector. This function cannot be fulfilled by the technology transfer office which comes into play only after the invention is created (Kenney and Patton, 2009; Landry et al., 2013). Faculty involvement in technology transfer through royalty or equity (Jensen and Thursby, 2001) will not solve this issue either.

In sum, given that the private sector produces most of the patents and that it is more likely to source itself within its own institutional boundaries when inventions are complex, and that complementary assets possessed by private sector organizations help the latter in identifying major trajectory outposts, we hypothesize that:

Hypothesis H1. Increases in recombination distance by the private sector leads to higher increases in invention basicness.

\subsection{Cognitive distance and science linkage strength}

According to Nooteboom et al. (2007), too much cognitive distance between knowledge owned and explored is detrimental to its transfer. Distant recombination requires a broader absorptive capacity from both the agent that performs it and those that eventually adopt it. The difficulty encountered by firms in absorbing external knowledge can explain why many inventions resulting from distant recombination end-up being failures (Nemet and Johnson, 2012). Also, firm absorptive capacity, which is linked to preferred search heuristics, can impact its ability to license distant technologies (Laursen et al., 2010). 
Proximity to basic sciences leads to the creation of innovations that have broad applications. However, beside the risk associated to the many failures that it can cause (Kim et al., 2012), knowledge that is close to basic research is more difficult to absorb outside the academic environment, that is a locus where access to basic science is the strongest (Cohen and Levinthal, 1990; Nooteboom et al., 2007). This observation hints at the direction that inventions that have strong linkage with basic sciences will not always succeed in finding adoption. Being strongly linked to basic science can thus be an inhibitor when it comes to invention diffusion.

Incidentally, if new technologies that are close to basic science result from distant recombination, it could be that they have too much cognitive distance from what can be promptly absorbed in the industry. There could be a case of knowledge that is "too theoretical" to be easily absorbed (Gilsing et al., 2011). Given that firms operate under conditions of time constraint in which they tend to prefer short-term solutions to current problems (Lynn et al., 1996; Tushman and O'Reilly III, 1996), such cognitively different inventions can be overlooked or too difficult to incorporate within search. In other words, such inventions could potentially have a very broad impact, but they could also be too innovative to satisfy immediate needs (McGrath, 2001; Lo et al., 2012). We thus hypothesize that:

Hypothesis H2. The interaction between the strength of linkage to basic sciences and recombination distance is negatively associated with invention basicness.

\subsection{Industry characteristics and preferred search heuristics}

From an industry evolution perspective, preferred search heuristics can evolve as industries evolve from periods of radical change to periods of incremental improvements (Dosi, 1982; Tushman and Anderson, 1986; Abernathy and Utterback, 
1978). Industry birth is generally initiated with the occurrence of "competencedestroying discontinuities" (Tushman and Anderson, 1986). These breakthroughs can result from the confluence of existing technologies and threaten the technological dominance of incumbent firms (Maine et al., 2014). In the early days of an industry, most research effort is spent on positioning against a "dominant design" built around the technological breakthrough (Utterback and Abernathy, 1975; Anderson and Tushman, 1990). This stage is marked by great turbulence as new entrants will explore and recombine distant technological components to find solutions that will become the dominant design. Once a dominant design is adopted, technological development becomes focused and cumulative as components are improved over time (Utterback and Abernathy, 1975; Anderson and Tushman, 1990). As a result, a concentration of inventive activity can be seen along trends toward more incremental improvements (Utterback and Suárez, 1993).

Breakthroughs that have competence-destroying potential do not always displace incumbents. In fact, Tripsas (1997) argues that the latter can leverage their dynamic capabilities and complementary assets to withstand newcomer attacks. In such cases, discontinuities can be "competence-enhancing" and thus reinforce incumbent position (Tushman and Anderson, 1986). When the discontinuity is dependent upon complementary assets owned by the incumbent, or when the latter has the ability to adapt to the discontinuity, the expected turbulent period of technological exploration by new entrants does not occur. As a result, inventive effort can continue to be focused and cumulative in nature.

Sectoral patterns can also dictate the type of research heuristics that will appear to be attractive. Literature reporting successful university-industry technology transfer in science-based industries such as biotechnology and pharmaceu- 
ticals is aplenty (Trajtenberg et al., 1997; Etzkowitz, 1998; Zucker et al., 2002; Gittelman and Kogut, 2003; Owen-Smith and Powell, 2004; Mowery and Sampat, 2005; Nikulainen and Palmberg, 2010; Gilsing et al., 2011; Lissoni, 2012). In development-based industries, however, there is a higher dependency on nonacademic research (Gilsing et al., 2011). In these fields, the bulk of inventive activity consists in incremental advances that were almost exclusively the domain of industrial R\&D (Mowery and Sampat, 2005). One could thus argue that there is a fit between university capabilities in performing basic and exploratory research and the needs of firms in science-based industries. We thus expect the relationship between recombination distance and invention basicness to be positively moderated by industry fragmentation and science-based nature of inventive activity and propose our last hypothesis:

Hypothesis H3. Increases in recombination distance in fragmented sciencebased industries leads to higher increases in invention basicness.

\section{Methodology}

\subsection{Data}

We analyze a sample of patents from the Canadian nanotechnology industry registered in the US. Nanotechnology is an emerging and multidisciplinary field, which makes a great locus for novel creations. The US represent the largest global market and are the most important economic partner for Canada. Li et al. (2007) show that the US is the first foreign destination in which Canadian firms file for patents. Barirani et al. (2013) offer a lexical query for the extraction and clustering of technologically similar "Canadian-made" nanotechnology patents. The study identifies three broad fields of expertise in Canada: nanobiotechnology, display 
technologies and optics. Because the method employed by the study only takes into account patents connected to the main network component, the whole set of patents that are extracted from the lexical query are not classified. We use the title and abstracts from the main network component's classified patents to train a $K$-NN model that would subsequently classify the non-connected patents into the three fields of expertise. We then select patents that were granted from 1990 to 1997 for which we extract information regarding their grant date, inventors, number of claims, and forward citations until year 2009. Patents for which no assignees are specified, as well as those that were co-assigned to public and private organizations (the latter case only includes three patents) were removed. The final sample contains 848 patents.

\subsection{Dependent variable}

Given a patent with $n$ forward citations falling into $m$ 3-digit classes, Trajtenberg et al. (1997) measure the degree with which future use of a patent spans technological classes with the following equation:

$$
\text { BAS ICNESS }=1-\sum_{i=1}^{m}\left(\frac{C L A S S_{i}}{n}\right)^{2}
$$

Where $C L A S S_{i}$ is the number of the patent's forward citations that fall within class $i$. As this value gets closer to zero, future inventions are limited in a narrow set of technological areas (which we call focused inventions), and a value closer to one indicates a more basic invention which is used in numerous technological areas.

To compute this value, we use patents' forward citations for a 12-year period after the grant year. This is justified by the fact that technological breakthroughs 
enjoy a rather slower adoption rate due to their inherent complexity (Schoenmakers and Duysters, 2010). Furthermore, patents that receive citations for a longer period are more likely to be important patents since high rates of technological obsolescence in high-technology industries means that lower quality patents could stop receiving citations earlier in their lifetime.

\subsection{Independent variables}

Given a patent with $p$ backward citations falling into $q$ 3-digit classes, the degree with which a patent combines technologies from distant classes can be computed with the following equation:

$$
\text { DISTANCE }=1-\sum_{i=1}^{q}\left(\frac{C L A S S_{i}}{p}\right)^{2}
$$

This variable measures the distance between technological components that were recombined to create an invention. As this value gets closer to zero, we are dealing with local recombination, and as it gets closer to one, we are dealing with distant recombination.

Prior studies indicate that within the three major areas of expertise, nanobiotechnology (encompassing nanotechnology-based pharmaceutical and biotechnology applications) is a science-based industry with low levels of concentration of patents in few firms (Barirani et al., 2013). Indeed, public institutions play a central role in the patent co-citation network. Similar patterns were found in the initial days of the biotechnology industry (Owen-Smith and Powell, 2004). The other disciplines are dominated by a smaller number of players and thus exhibit concentration although, given their activities in the nanotechnology industry, these industries are obviously very knowledge intensive. The main difference between 
nanobiotechnology and the other industries (optics and display technologies) is that it can answer to needs that could not be answered previously (such as applications of drug delivery allow for new types of treatment that are not possible without the application of nanoscale technologies), whereas the others are merely using new technology to answer existing needs. In these industries, one can assume that incumbents were able to adapt nanotechnology components and that many of the complementary assets owned by them have kept their value. Thus, to distinguish between emerging and mature industries, we will add the dummy variable $N A N O B I O$ using the patent classification process described earlier.

We account for the sector of activity (private or public) using information on patent assignees. Patents are classified based on whether they are owned by corporations or public organizations, the latter including universities. We employ the dummy variable PRIVATE to identify corporations.

We use the number of non-patent references $(N P R S)$ as a proxy for the strength of the linkage between a patent and basic science. Callaert et al. (2006) find that most NPRS are references to scientific journals, and that a greater share of NPRS are made to scientific journals in knowledge intensive industries. Given the emerging nature of the nanotechnology industry, we thus believe that it is reasonable to use the number of non-patent references to measure proximity to basic science.

\subsection{Control and dummy variables}

The variable DISTANCE is dependent upon the number of backward citations that a patent contains. In other words, the higher is the number of backward citations, the higher is the probability that all of them are not assigned to one class. To account for this, we propose to control the degree of distant recombination by 
the patent' total number of backward-citations (NCITBACK). Similarity, variable BASICNESS can be influenced by the number of forward citations. We thus add control variable NFORWCIT to our model which is a measure of the number of forward citations for a 12-year period after the patent's grant year.

The scope of a patent's claims determines the monopoly power of the patent holder by defining the main novel features of the invention (Merges and Nelson, 1990). Inventors have an incentive to claim as much as possible while patent examiners must narrow down the scope of the patent before granting it (Lanjouw and Schankerman, 2004). The number of claims can therefore be used as an indication of a patent's quality (Tong and Frame, 1994). Patents that claim more are thus more likely to restrict the scope of other patents which also translates into being cited by those restricted patents. This in turn can have an impact on the diffusion pattern of a patent. We thus employ the variable CLAIMS which counts the number of claims a patent makes to control for its impact on basicness. Technology classes in which a patent falls can also be used to measure its scope (Lerner, 1994). We use the variable SCOPE to measure the number of distinct 3-digit US classes to which each patent is assigned. The addition of this variable also controls for the fact that examiner citations are closely linked to the technological classes in which patents fall (Lerner, 1994). In other words, inventions that fall in numerous classes will have a higher likelihood of citing (and eventually being cited by) patents from various classes. SCOPE will thus control the part of an invention's basicness that is due to the classification performed by USPTO examiners.

Organizational experience in patenting can also have an impact on diffusion outcome. This is especially true for universities whose accumulated experience in patenting and technology transfer can have a positive impact on the adoption 
of their inventions on the marketplace (Thursby and Thursby, 2007). We control for experience in patenting in two ways. First by measuring the total number of nanotechnology patents that a patent holder obtains between the 1990-1997 period. We report this variable as NBPATS. It should be noted that the number of patents obtained by the same firms in various periods (ex: between 1980-1989 and 1990-1997) is strongly correlated for the organizations in our sample (greater than 0.75$)$. Second, we compute a 5-year moving sum representing all the patents owned by an assignee 5 years prior to the obtainment of a new patent. This variable is reported as EXPERIENCE.

Since many advantages can be associated with being part of a patent's inventing team, it is natural to assume that only those who bring distinctive skills to the table will have the power to earn a place among the list of inventors. For instance, if an invention results from the work of a team composed of one senior-level researcher or engineer and a few junior-level engineers who play a less critical role in the development of the invention, it is more likely that only the senior-level member will end up as the sole inventor. In contrast, if a complex invention requires the involvement of many senior-level researchers and scientists who each come with their own special skills, then chances are that they will have to come to an agreement to include all of them in the list of inventors. Since it is not likely that one individual has enough expertise to cover a broad range of technologies, we are expecting to see that teams composed of a greater number of inventors should cover different technological areas. We thus control for team size through variable TEAMSIZE, which measures the number of investors listed in a patent.

Time can have various effects on patent metrics. For instance, technological progress goes through different stages, which can be visible over time, and poli- 
cies can have an impact on patenting activity. Numerous studies therefore use the patent's grant date to control for various factors that may affect dependent variables (Schoenmakers and Duysters, 2010; Nemet and Johnson, 2012). We also use the patent grant year to account for unmeasured time effects. This is represented by year dummy variables Y1991 to Y1997.

\subsection{Interaction variables}

To measure the moderating impact of the type of activity (private-public dichotomy), science linkage and industry emergence, three interaction variables will be considered in this study. The interaction between DISTANCE and PRIVATE will show how distant recombination performed by firms results in basic inventions, compared to the public research institutions. The interaction between DISTANCE and NPRS will show how the strength of science linkage will lead to more basic inventions. Given that these two variables are continuous, a positive coefficient will indicate that distant recombination and science-linkage have impact in the same direction, while a negative coefficient will indicate that the two variables work in opposite directions. The interaction between DISTANCE and NANOBIO will indicate whether distant recombination in the emerging nanobiotechnology industry leads to more basic inventions, compared to the two other technologies (optics and display).

\subsection{Models}

In attempting to link distant recombination with invention basicness, our methodology mainly consists in analyzing the statistical relationship between the spread of a patent's backward-citations with that of its forward-citations. We therefore associate recombination distance with the use of inventions from a multitude of 
disciplines during research and its basicness with its use by subsequent inventions in a multitude of disciplines. Because we also try to measure the impact of institutional differences (H1), science-linkage strength (H2) and industry characteristics (H3), we perform a hierarchical analysis that will measure the moderating effect of these factors over the relationship between recombination distance and invention basicness.

Because our dependent variable is continuous, our main statistical method will use ordinary least squares (OLS). Since many patents will fall within the definition of focused inventions and will have a value of zero, we use the left censored Tobit model to test the robustness of our OLS model. Furthermore, for each model, robust variance estimates are computed through "clustered sandwich estimator" method (Rogers, 1987) using patent assignee names as cluster authenticators. This is justified by the fact that organizational practices in patenting can have an impact on diffusion outcome. For large patent holders, there can be correlation among observations (patents) given the cumulative nature of technology development for these organizations.

\section{Analysis and Results}

\subsection{Descriptive statistics}

Table 1 shows the correlation matrix for all variables (except YEAR dummies). One can see a positive relationship between DISTANCE and BASICNESS, which goes in the direction of our first hypothesis. It is also worth discussing the relationship between variables NPRS, PRIVATE and NANOBIO. These results corroborate findings about the nature of activities in the biotechnology industry (Barirani et al., 2013), compared to the other two industries. Indeed, we can see that pub- 
lic institutions are more present in the nanobiotechnology industry. Furthermore, organizations in this industry appear to have stronger links with basic sciences. Some other finding can be corroborated by our data. For instance, PRIVATE is negatively correlated with NPRS as it is often observed (Dasgupta and David, 1994; Stephan, 1996; Trajtenberg et al., 1997).

One can notice a strong correlation between DISTANCE and NCITBACK (and with SCOPE to a smaller extent), and thus the possibility of multicollinearity. One should note that these variables are naturally confounded given the correlation between examiner classifying patents in multiple classes and citing (many) patents from multiple classes. Nonetheless, the regression results shown in the following sections are robust with regards to this degree of correlation. For instance, removing variable NCITBACK (these estimations are, however, not reported here) from models 2 to 6 in tables 2 and A.4 yields very similar results. It thus appears that the variable DISTANCE contains information that encompasses that of NCITBACK. Also, measuring variance inflator factor (VIF) for models 1 and 2 in table 2 both give a value of 1.86 and 1.73 respectively, which is below generally recommended maximum value (Neter et al., 1985; Hair et al., 2009). Models 3 to 6, which include interaction variables, are also below the rule-of-thumb threshold. Our view is that although our data exhibits some level of multicollinearity between certain variables, enough information is contained in each of them to allow for discrimination between observations.

\subsection{Inferential statistics}

Tables 2 to A.5 present our results for the OLS and Tobit models. Because estimates for these models are very similar, we will refer to the results from the OLS models using NBPAT in the following discussion. Model 1 shows that the 


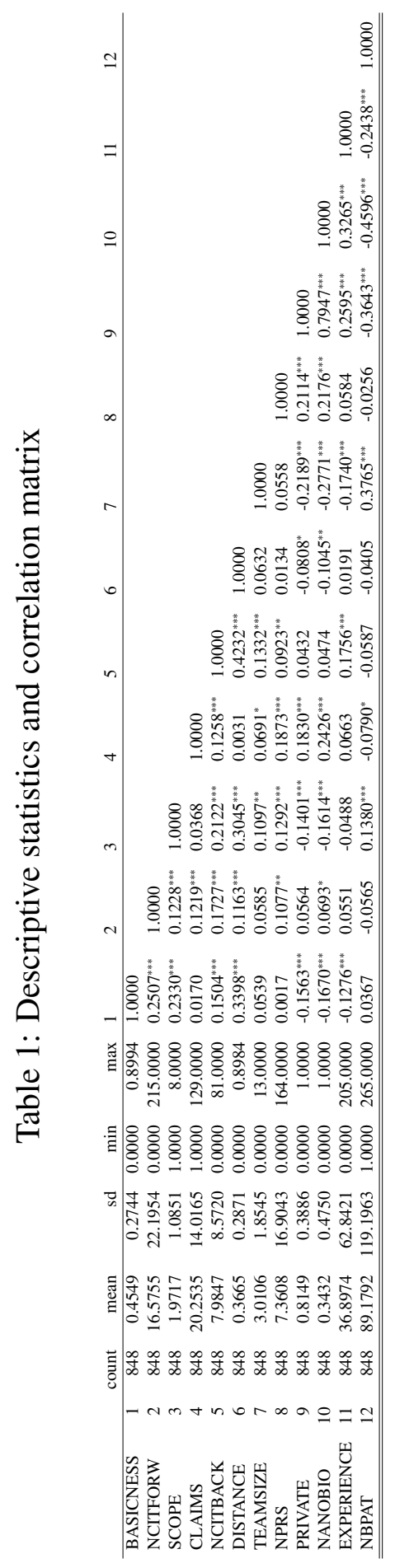


link between the number of forward citations and patent basicness is significant. As expected, we find a positive relationship between SCOPE and BASICNESS. Similarly, the total number of backward citations has a positive relationship with BASICNESS.

Model 2 takes into account the independent variables to our experiment and is an improvement over model 1: adding recombination distance to the model improves its explanatory power. We find a negative and significant relationship between PRIVATE and basicness. This observation corroborates the findings that firms produce a smaller share of basic inventions. The model also shows a significant relationship between DISTANCE and basicness, but interestingly, the impact from the number of backward citations $(N C I T B A C K)$ on invention basicness is no longer significant when we control for distant recombination. It appears that, all things being equal, patents that result from the combination of technologies from different fields will turn out to be eventually used in a multitude of disciplines. These findings are in line with Trajtenberg et al. (1997) and Banerjee and Cole (2010).

Model 6 incorporates interaction effects with DISTANCE (models 3 to 5 incorporate interactions one-by-one for robustness checking). As we can see, the interaction between DISTANCE and PRIVATE results into a significant and positive relationship with basicness. It thus appears that whether the patent holder is a private or public organization has an impact on the degree with which inventions diffuse across disciplines as recombination distance increases. Given that PRIVATE is negatively associated with BASICNESS, this implies that public organizations produce higher rates of basic inventions at lower values recombination distance and that this difference between private and public sector dissipates as 
Table 2: Results - OLS regressions using NBPAT.

\begin{tabular}{|c|c|c|c|c|c|c|c|c|c|}
\hline & (1) & (2) & (3) & (4) & (5) & (6) & (7) & (8) & (9) \\
\hline NCITFORW & $\begin{array}{c}0.0027^{* * * * *} \\
(0.0005)\end{array}$ & $\begin{array}{c}0.0027^{* * * * *} \\
(0.0004)\end{array}$ & $\begin{array}{c}0.0027^{* * * * *} \\
(0.0004)\end{array}$ & $\begin{array}{c}0.0027^{* * * * *} \\
(0.0004)\end{array}$ & $\begin{array}{c}0.0026^{* * * * *} \\
(0.0004)\end{array}$ & $\begin{array}{c}0.0026^{* * * * *} \\
(0.0004)\end{array}$ & $\begin{array}{c}0.0029^{* * * * *} \\
(0.0006)\end{array}$ & $\begin{array}{c}0.0029^{* * * * *} \\
(0.0004)\end{array}$ & $\begin{array}{c}0.0033^{* * * * *} \\
(0.0006)\end{array}$ \\
\hline NCITBACK & $\begin{array}{l}0.0028^{*} \\
(0.0015)\end{array}$ & $\begin{array}{l}-0.0000 \\
(0.0015)\end{array}$ & $\begin{array}{l}-0.0001 \\
(0.0015)\end{array}$ & $\begin{array}{c}0.0005 \\
(0.0016)\end{array}$ & $\begin{array}{l}-0.0001 \\
(0.0016)\end{array}$ & $\begin{array}{c}0.0002 \\
(0.0016)\end{array}$ & $\begin{array}{l}-0.0011 \\
(0.0018)\end{array}$ & $\begin{array}{c}0.0001 \\
(0.0017)\end{array}$ & $\begin{array}{l}-0.0010 \\
(0.0018)\end{array}$ \\
\hline SCOPE & $\begin{array}{c}0.0389^{* * * *} \\
(0.0134)\end{array}$ & $\begin{array}{l}0.0250^{* *} \\
(0.0119)\end{array}$ & $\begin{array}{l}0.0246^{* *} \\
(0.0119)\end{array}$ & $\begin{array}{l}0.0239^{* *} \\
(0.0120)\end{array}$ & $\begin{array}{l}0.0260^{* * *} \\
(0.0115)\end{array}$ & $\begin{array}{l}0.0252^{* * *} \\
(0.0115)\end{array}$ & $\begin{array}{c}0.0115 \\
(0.0100)\end{array}$ & $\begin{array}{l}0.0246^{* *} \\
(0.0123)\end{array}$ & $\begin{array}{c}0.0102 \\
(0.0108)\end{array}$ \\
\hline CLAIMS & $\begin{array}{c}0.0003 \\
(0.0007)\end{array}$ & $\begin{array}{c}0.0005 \\
(0.0006)\end{array}$ & $\begin{array}{c}0.0005 \\
(0.0006)\end{array}$ & $\begin{array}{c}0.0005 \\
(0.0006)\end{array}$ & $\begin{array}{c}0.0005 \\
(0.0006)\end{array}$ & $\begin{array}{c}0.0005 \\
(0.0006)\end{array}$ & $\begin{array}{c}0.0009 \\
(0.0008)\end{array}$ & $\begin{array}{c}0.0006 \\
(0.0007)\end{array}$ & $\begin{array}{c}0.0011 \\
(0.0008)\end{array}$ \\
\hline TEAMSIZE & $\begin{array}{l}-0.0027 \\
(0.0059)\end{array}$ & $\begin{array}{l}-0.0014 \\
(0.0056)\end{array}$ & $\begin{array}{l}-0.0015 \\
(0.0055)\end{array}$ & $\begin{array}{l}-0.0009 \\
(0.0057)\end{array}$ & $\begin{array}{l}-0.0013 \\
(0.0056)\end{array}$ & $\begin{array}{l}-0.0006 \\
(0.0057)\end{array}$ & $\begin{array}{c}0.0078 \\
(0.0067)\end{array}$ & $\begin{array}{l}-0.0018 \\
(0.0051)\end{array}$ & $\begin{array}{c}0.0062 \\
(0.0067)\end{array}$ \\
\hline NBPAT & $\begin{array}{c}-0.0004^{* * * * * *} \\
(0.0001)\end{array}$ & $\begin{array}{c}-0.0003^{* * * *} \\
(0.0001)\end{array}$ & $\begin{array}{c}-0.0003^{* * * *} \\
(0.0001)\end{array}$ & $\begin{array}{c}-0.0003^{* * * *} \\
(0.0001)\end{array}$ & $\begin{array}{c}-0.0003^{* * * *} \\
(0.0001)\end{array}$ & $\begin{array}{c}-0.0003^{* * * *} \\
(0.0001)\end{array}$ & $\begin{array}{c}-0.0016^{* * * *} \\
(0.0006)\end{array}$ & $\begin{array}{c}-0.0003^{* * *} \\
(0.0001)\end{array}$ & $\begin{array}{l}-0.0010 \\
(0.0024)\end{array}$ \\
\hline GRANTYEAR & yes & yes & yes & yes & yes & yes & yes & yes & yes \\
\hline DISTANCE & & $\begin{array}{c}0.2599^{* * * * *} \\
(0.0291)\end{array}$ & $\begin{array}{c}0.1655^{* * * * *} \\
(0.0465)\end{array}$ & $\begin{array}{c}0.2855^{* * * * *} \\
(0.0325)\end{array}$ & $\begin{array}{c}0.2351^{* * * * *} \\
(0.0347)\end{array}$ & $\begin{array}{l}0.1407^{* *} \\
(0.0602)\end{array}$ & $\begin{array}{l}0.1270^{* *} \\
(0.0629)\end{array}$ & $\begin{array}{l}0.1368^{* *} \\
(0.0603)\end{array}$ & $\begin{array}{l}0.1203^{*} \\
(0.0640)\end{array}$ \\
\hline NPRS & & $\begin{array}{l}-0.0006 \\
(0.0006)\end{array}$ & $\begin{array}{l}-0.0006 \\
(0.0005)\end{array}$ & $\begin{array}{c}0.0011 \\
(0.0007)\end{array}$ & $\begin{array}{l}-0.0006 \\
(0.0005)\end{array}$ & $\begin{array}{l}0.0015^{*} \\
(0.0008)\end{array}$ & $\begin{array}{l}0.0014^{*} \\
(0.0008)\end{array}$ & $\begin{array}{l}0.0015^{*} \\
(0.0008)\end{array}$ & $\begin{array}{c}0.0014^{*} \\
(0.0008)\end{array}$ \\
\hline PRIVATE & & $\begin{array}{c}-0.0760^{* * *} \\
(0.0294)\end{array}$ & $\begin{array}{c}-0.1191^{* * *} \\
(0.0387)\end{array}$ & $\begin{array}{c}-0.0757^{* * *} \\
(0.0294)\end{array}$ & $\begin{array}{c}-0.0755^{* *} \\
(0.0295)\end{array}$ & $\begin{array}{c}-0.1187^{* * * *} \\
(0.0396)\end{array}$ & $\begin{array}{c}-0.1118^{* * *} \\
(0.0405)\end{array}$ & $\begin{array}{c}-0.1153^{* * *} \\
(0.0397)\end{array}$ & $\begin{array}{c}-0.1096^{\text {**** }} \\
(0.0415)\end{array}$ \\
\hline NANOBIO & & $\begin{array}{c}-0.0144 \\
(0.0237)\end{array}$ & $\begin{array}{c}-0.0139 \\
(0.0237)\end{array}$ & $\begin{array}{c}-0.0143 \\
(0.0235)\end{array}$ & $\begin{array}{c}-0.0385 \\
(0.0372)\end{array}$ & $\begin{array}{l}-0.0667^{*} \\
(0.0362)\end{array}$ & $\begin{array}{c}-0.0972^{* * *} \\
(0.0347)\end{array}$ & $\begin{array}{l}-0.0724^{*} \\
(0.0388)\end{array}$ & $\begin{array}{c}-0.1000^{* * * *} \\
(0.0367)\end{array}$ \\
\hline DISTANCEXPRIVATE & & & $\begin{array}{l}0.1202^{* *} \\
(0.0527)\end{array}$ & & & $\begin{array}{l}0.1229^{* *} \\
(0.0584)\end{array}$ & $\begin{array}{l}0.1164^{*} \\
(0.0603)\end{array}$ & $\begin{array}{l}0.1242^{* *} \\
(0.0584)\end{array}$ & $\begin{array}{l}0.1154^{*} \\
(0.0624)\end{array}$ \\
\hline DISTANCExNPR & & & & $\begin{array}{c}-0.0041^{* *} \\
(0.0016)\end{array}$ & & $\begin{array}{c}-0.0050^{* * * *} \\
(0.0018)\end{array}$ & $\begin{array}{c}-0.0048^{* * *} \\
(0.0019)\end{array}$ & $\begin{array}{c}-0.0051^{* * *} \\
(0.0018)\end{array}$ & $\begin{array}{c}-0.0050^{* * * *} \\
(0.0019)\end{array}$ \\
\hline DISTANCEXNANOBIO & & & & & $\begin{array}{c}0.0647 \\
(0.0619)\end{array}$ & $\begin{array}{l}0.1420^{* *} \\
(0.0628)\end{array}$ & $\begin{array}{c}0.1773^{\text {**** }} \\
(0.0668)\end{array}$ & $\begin{array}{l}0.1431^{\text {*** }} \\
(0.0653)\end{array}$ & $\begin{array}{l}0.1809^{* *} \\
(0.0732)\end{array}$ \\
\hline Constant & $\begin{array}{c}0.2658^{* * * * *} \\
(0.0423)\end{array}$ & $\begin{array}{c}0.2812^{* * * * *} \\
(0.0493)\end{array}$ & $\begin{array}{c}0.3160^{* * * * * *} \\
(0.0537)\end{array}$ & $\begin{array}{c}0.2662^{* * * * *} \\
(0.0492)\end{array}$ & $\begin{array}{c}0.2903^{* * * * * *} \\
(0.0498)\end{array}$ & $\begin{array}{c}0.3183^{* * * * *} \\
(0.0561)\end{array}$ & $\begin{array}{c}0.3336^{* * * * *} \\
(0.0632)\end{array}$ & $\begin{array}{c}0.3347^{* * * * *} \\
(0.0555)\end{array}$ & $\begin{array}{c}0.3449^{* * * * *} \\
(0.0612)\end{array}$ \\
\hline Observations & 848 & 848 & 848 & 848 & 848 & 848 & 583 & 797 & 532 \\
\hline Clusters & 284 & 284 & 284 & 284 & 284 & 284 & 283 & 283 & 282 \\
\hline Log lik. & -38.4170 & -3.3836 & -2.0512 & -1.4403 & -2.8240 & 1.6292 & 15.1335 & -4.3385 & 8.2481 \\
\hline $\mathrm{F}$ & 17.6193 & 32.9509 & 30.1708 & 34.2517 & 32.5005 & 32.6476 & 12.9682 & 31.5472 & 9.0664 \\
\hline p-value & 0.0000 & 0.0000 & 0.0000 & 0.0000 & 0.0000 & 0.0000 & 0.0000 & 0.0000 & 0.0000 \\
\hline R-squared & 0.1478 & 0.2154 & 0.2178 & 0.2190 & 0.2164 & 0.2246 & 0.2219 & 0.2323 & 0.2282 \\
\hline Adjusted R-squared & 0.1345 & 0.1993 & 0.2009 & 0.2020 & 0.1994 & 0.2059 & 0.1943 & 0.2125 & 0.1979 \\
\hline
\end{tabular}

${ }^{*} p<0.1,{ }^{* *} p<0.05,{ }^{* * *} p<0.01,{ }^{* * * *} p<0.001$ 
recombination distance increases. This finding supports $\mathrm{H} 1$ that while the relationship between recombination distance and invention basicness is still positive for public organizations, an increase of one unit in recombination distance can be linked to a greater increase in invention basicness in the private sector. As we can see in figure 1a, distant recombination by the private sector eventually surpasses the public sector (in terms of associated patent basicness), but this is the case for very large values. One should note that our sample does not contain such large values of DISTANCE.

As expected, we observe a negative and significant relationship between $B A$ SICNESS and the interaction of DISTANCE and NPRS. It thus appears that combining distant technologies and depending heavily on basic science have a negative impact on the patent's diffusion over multiple disciplines. Again, this interaction effect does not mean that the resulting invention will be useless. However, it implies that such inventions do not succeed in reaching the broad adoption that one expects the results of combining basic knowledge should have. It should be noted that there is a positive significant relationship between NPRS and BASICNESS for models 4 and 6 where NPRS interact with DISTANCE. In other models where the interaction between NPRS and DISTANCE is not included, the relationship between NPRS and BASICNESS is negative although not significant. Our interpretation of this phenomenon is that observations for which NPRS and DISTANCE are both high appear to drag down the coefficient of $N P R S$ when interaction effects are not taken into account. Our take is that exploratory research (either through strong scientific linkage or distant technological recombination) can be generally linked with inventions basicness, but that interaction between different modes of exploration can lead to difficult absorption and thus decreased observed basicness. 


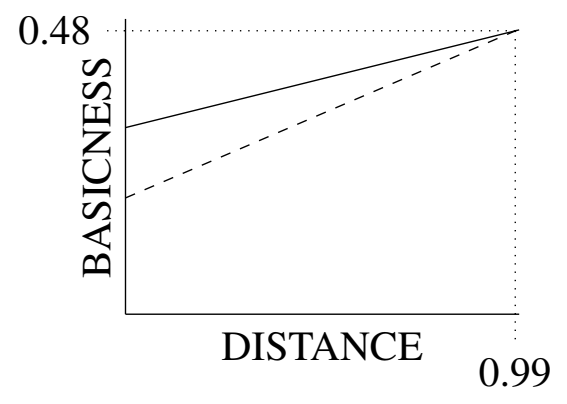

(a) Model 3

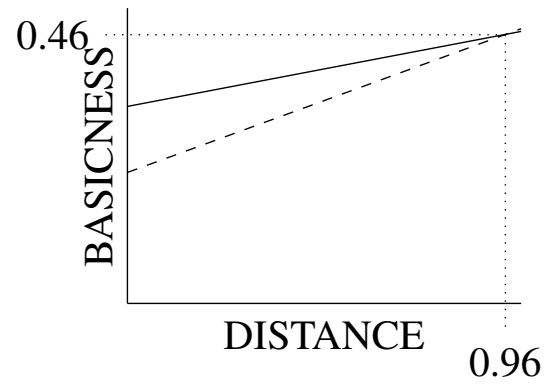

(c) Model 7

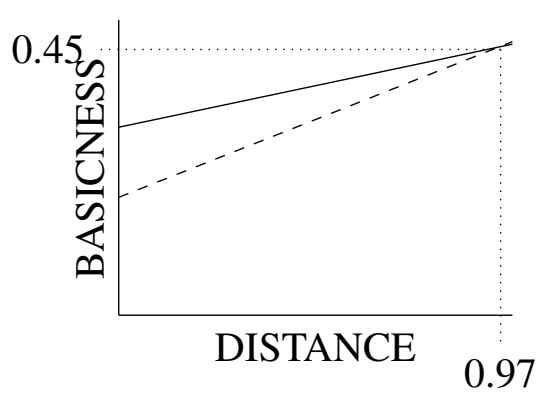

(b) Model 6

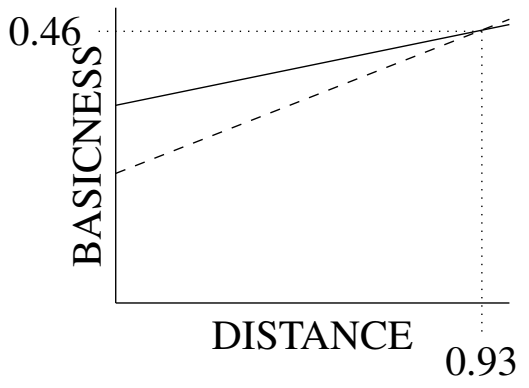

(d) Model 8

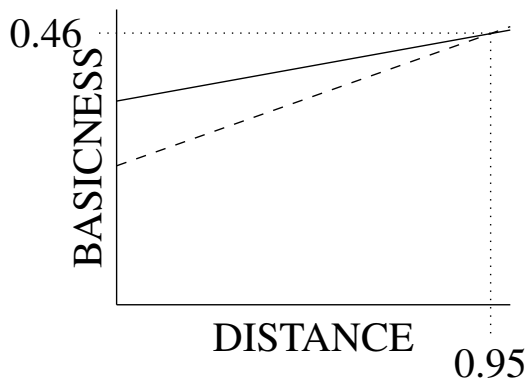

(e) Model 9

Figure 1: Regression lines for models 3, 6, 7, 8 and 9 from table 2 (using NBPAT). Solid and dashed lines represent regression lines for the public and the private sector respectively. Dotted lines represent the value of DISTANCE at which the private sector produces basic inventions at a higher rate. Both DISTANCE and $B A S I C N E S S$ are in the interval [0,1[. Note that the highest value of DISTANCE in our sample is 0.8984 . 
These findings support $\mathrm{H} 2$ in that the exploratory search involving distant technological recombination and strong linkage with basic sciences is negatively related to invention basicness.

We find a positive and significant relationship between basicness and the interaction of DISTANCE with NANOBIO. One should however notice that this feature of the industry is not apparent when we do not control for other interactions (as in model 5). In fact, science linkage and inventive activity by public institutions is stronger in nanobiotechnology than other industries. Thus, the effect of these various forces (measured through NPRS and PRIVATE) impact the interaction of DISTANCE with NANOBIO. When controlling for these factors (in model 6), we see that distant recombination in nanobiotechnology, an emerging science-based industry, results in inventions that will have spread over various disciplines. These findings support $\mathrm{H} 3$.

Finally, given the skewed distribution of patents among organizations (a few organizations own many patents, while many organizations own a few patents), it is relevant to test whether the presence of large private patent holders introduces a bias in our results. We have run model 6 on separate samples removing the two largest patents holders: Xerox Corporation (with 265 patents) and Nortel Networks (with 51 patents). Model 7 removes Xerox Corporation, model 8 removes Nortel Networks and model 9 removes both firms. As we can see, results are sensibly the same as those reported above. We can say that the results are robust to the exclusion of the two largest patent holders, Xerox and Nortel. 


\section{Discussion and conclusion}

There is little consensus among scholars regarding the benefits of the academic enterprise model. One camp claims that universities can leverage markets for technology and use patenting as a way to finance their operations. The other camp claims that changing the reward and incentive system can have a negative impact on the type of research endeavored in universities. A large part of this debate has taken place around the presumption that distant recombination is linked to invention basicness, rendering possible the ability to take conclusions about a shift in the nature of research conducted within universities by examining shifts to the basicness of the patents they are granted. We argue that these assumptions do not fully take into consideration moderating factors that come into play.

The purpose of this paper is to test whether the relationship between recombination distance and invention basicness can be moderated by institutional differences, science-linkage strength and industry characteristics. We have conducted an econometric analysis by employing a sample of Canadian-invented nanotechnology patents granted between 1990 and 1997. Our results show that the above factors can indeed have moderating effects.

An interesting finding in our study is the ability of private organizations to transform the results of distant recombination into inventions that become basic in the future. This is despite the fact that public institutions are, overall, producing basic inventions at a higher rate. Therefore, while our results confirm other observations about a tendency of firms for short-term profits and exploitative activities (Ahuja and Lampert, 2001; Tushman and O'Reilly III, 1996), there appears to be more than meets the eye. Indeed, we find that firms can be more successful than public organizations in producing basic inventions under the condition that 
they engage in technological exploration. This finding also brings new insight about the involvement of universities in commercial activities. More precisely, even though universities could be better equipped in performing basic research, it does not mean that such efforts will be effectively transmitted into inventions that have a broad social impact. The skills for which universities are solicited (performing explorative research) does not appear to be the one leading to the desired effect of producing more socially useful inventions. In fact, it is when they perform local recombination (that is the opposite of what they are supposed to be good at) that public organizations appear to be distinguished from firms. This finding could appear counter intuitive in that, to the proponents of the academic enterprise, it could mean that universities should be performing more local recombination, which would implicitly call for them doing less basic research. The question would thus remain: who will do basic research if one does not expect public institutions to have more resources to fill the gap left?

Another contribution of this article is concerned with the impact of basic sciences on basic inventions. Proximity to basic science is often believed to be a source of inspiration for breakthrough creation. However, if one takes the risks associated with the failure of potential adopters to absorb novelties that are too complex, then combining both strong science linkage with distant recombination can have a detrimental effect on diffusion. In these cases, a new technology that has great potential could have been developed, but could also fail to find subsequent users. Given that the combined impact of distant recombination and basic science linkage move in opposite directions, our findings support the idea that inventions which are strongly sourced in basic sciences should be focused in one technological discipline to have maximum social impact. These findings are in 
line with study by Kim et al. (2012) about the trade-offs of scientific exploration.

Finally, our results show that distant recombination does not equally produce basic inventions in all domains. In the nanobiotechnology sector, where competition is high, distant recombination yields a greater amount of basic inventions. This is, to a certain degree, due to fact that mature industries will concentrate on focused inventions. In such fields, where a few players are dominant, inventions are cumulative in nature. $R \& D$ effort will therefore be concentrated on incremental improvement around the dominant designs. Introducing radically novel ways of doing things in such industries will not translate into proper level of adoption. This finding can be put in perspective with regards to ambidexterity (Tushman and O'Reilly III, 1996). The balance between exploration and exploitation can be dictated by industry development stage: when markets are turbulent, exploration is more likely to produce basic inventions; but when they are stable, exploitation is the type of activity that leads to basic inventions. This statement, however, does not suggest that basic inventions have better prospects of private returns in mature industries.

Looking at the whole picture, more can be said about the importance of university inventions in science-based industries (Mowery and Sampat, 2005). Our results seem to indicate that, when we control for sectoral effects (nanobiotechnology in this case) and science-linkage strength, the relationship between recombination distance and invention basicness is negatively moderated in the case of public organizations. In other words, without having to dispute the idea that university research has a much more important impact in science-based fields, the relevance of university patenting as the best way to foster university-industry technology transfer can still be questioned. 
Our study brings under scrutiny the idea that markets for technology will unleash the revenue generating capacity of the academic enterprise. Unless one's view about successful technology transfer requires heroic efforts by faculty members, research groups cannot be as efficient as firms in exploiting their ability to perform exploratory research unless they are able to integrate marketing resources for better sensing of technological opportunities. Further taking into account the impact that inter-institutional differences can have on invention diffusion adds another dimension to the problem. This perspective implies that even the ownership of complementary assets by universities (better patent office capabilities, more successful spinoff generation, stronger industry ties) might not completely overcome the institutional distance that impedes the transfer of complex technologies to the private sector.

This paper does not intent to question the possibility that universities could be able to appropriate returns on research that they endeavor. However, to the extent where part of the trend in academic patenting is motivated by a replacement of decreasing public funds, our study suggests that it is worthwhile to further study the efficiency of such trends especially when considering differences in capabilities between private and public institutions. The fact that lack of funding pushes universities towards commercial avenues should be questioned instead of be treated for granted. An interpretation of our study would be that favoring distant recombination within firms might be a better policy from a social point of view. This does not rule out considering ways to foster university-industry technology transfer that do not automatically call for more patenting or competitive behavior by public sector organizations (D'Este and Patel, 2007; Yusuf, 2008). One should note that our findings do not automatically imply that the production of basic patents by the 
public sector is cost ineffective: institutional differences between the private and the public sector could mean different cost functions to distant recombination that would favor performing this kind of research in the public sector.

An inherent limit of our study is in the use of US classes to measure recombination distance and invention basicness. The problem arises from the fact that US classes are not defined hierarchically. All three-digit US classes are at the same level and do not contain information about proximity between classes. Thus, two patents can have the same value for recombination distance but combine technological classes that are at different distances. Our Herfindahl-based index measuring recombination distance and invention basicness is bound between zero and one and thus does not fully reflect the highly skewed distribution of invention impact. Building co-citation networks and measures of distant recombination (basicness) through centrality metrics, such as the betweenness metric, can offer interesting methodological opportunities to palliate these shortcomings. Also, our study is limited to the case of the Canadian nanotechnology sector. Similar experiments with larger samples or other industries can be used to corroborate the findings of this study. Finally, our study does not take into consideration how various practices within the public sector (ex: size of technology transfer office, faculty involvement with industry, spinoff creation) moderate the relationship between recombination distance and invention basicness. Nonetheless, one should notice that various practices within the private sector can also lead to different outcomes in terms of patent diffusion: one cannot claim that all firms are adopting best practices and obtaining optimal outcomes to their research effort. Our study thus assumes that the adoption of best practices in the private and public sector follow similar distributions. Although this feature is intentional in that its aim is 
to illustrate the impact of institutional differences, it is nevertheless important to further study whether certain practices can fill the institutional gap in capabilities between the private and public sector without jeopardizing the production of basic knowledge.

\section{Appendix A. Appendices}

\section{References}

Abernathy, W. J., Utterback, J., 1978. Patterns of industrial innovation. Technology Review 80 (7), 40-47.

Acosta, M., Coronado, D., Martínez, M., 2012. Spatial differences in the quality of university patenting: Do regions matter? Research Policy 41 (4), 692-703.

Acs, Z. J., Audretsch, D. B., 1989. Patents as a measure of innovative activity. Kyklos 42 (2), 171-80.

Adams, J. D., 1990. Fundamental stocks of knowledge and productivity growth. Journal of Political Economy 98 (4), 673-702.

Ahuja, G., Lampert, C., 2001. Entrepreneurship in the large corporation: A longitudinal study of how established firms create breakthrough inventions. Strategic Management Journal 22 (6-7), 521-543.

Alcácer, J., Gittelman, M., 2006. Patent citations as a measure of knowledge flows: The influence of examiner citations. Review of Economics and Statistics 88 (4), 774-779.

Alcácer, J., Gittelman, M., Sampat, B., 2009. Applicant and examiner citations in u.s. patents: An overview and analysis. Research Policy 38 (2), 415-427. 
Table A.3: Results - OLS regressions using EXPERIENCE.

\begin{tabular}{|c|c|c|c|c|c|c|c|c|c|}
\hline & (1) & (2) & (3) & (4) & (5) & (6) & (7) & (8) & (9) \\
\hline NCITFORW & $\begin{array}{c}0.0027^{* * * * *} \\
(0.0004)\end{array}$ & $\begin{array}{c}0.0027^{* * * * *} \\
(0.0004)\end{array}$ & $\begin{array}{c}0.0027^{* * * * *} \\
(0.0004)\end{array}$ & $\begin{array}{c}0.0027^{* * * * *} \\
(0.0004)\end{array}$ & $\begin{array}{c}0.0026^{* * * * *} \\
(0.0004)\end{array}$ & $\begin{array}{c}0.0026^{* * * * *} \\
(0.0003)\end{array}$ & $\begin{array}{c}0.0029^{* * * * *} \\
(0.0006)\end{array}$ & $\begin{array}{c}0.0029^{* * * * *} \\
(0.0004)\end{array}$ & $\begin{array}{c}0.0033^{* * * * *} \\
(0.0006)\end{array}$ \\
\hline NCITBACK & $\begin{array}{c}0.0025^{*} \\
(0.0014)\end{array}$ & $\begin{array}{c}-0.0003 \\
(0.0015)\end{array}$ & $\begin{array}{c}-0.0004 \\
(0.0015)\end{array}$ & $\begin{array}{c}0.0002 \\
(0.0015)\end{array}$ & $\begin{array}{c}-0.0004 \\
(0.0015)\end{array}$ & $\begin{array}{l}-0.0001 \\
(0.0016)\end{array}$ & $\begin{array}{l}-0.0011 \\
(0.0018)\end{array}$ & $\begin{array}{l}-0.0002 \\
(0.0016)\end{array}$ & $\begin{array}{l}-0.0011 \\
(0.0018)\end{array}$ \\
\hline SCOPE & $\begin{array}{l}0.0404^{* * *} \\
(0.0137)\end{array}$ & $\begin{array}{l}0.0250^{* *} \\
(0.0117)\end{array}$ & $\begin{array}{l}0.0246^{* *} \\
(0.0117)\end{array}$ & $\begin{array}{l}0.0240^{* *} \\
(0.0118)\end{array}$ & $\begin{array}{l}0.0260^{* *} \\
(0.0113)\end{array}$ & $\begin{array}{l}0.0253^{* *} \\
(0.0113)\end{array}$ & $\begin{array}{c}0.0119 \\
(0.0100)\end{array}$ & $\begin{array}{l}0.0248^{* *} \\
(0.0121)\end{array}$ & $\begin{array}{c}0.0105 \\
(0.0108)\end{array}$ \\
\hline CLAIMS & $\begin{array}{c}0.0001 \\
(0.0008)\end{array}$ & $\begin{array}{c}0.0004 \\
(0.0007)\end{array}$ & $\begin{array}{c}0.0004 \\
(0.0007)\end{array}$ & $\begin{array}{c}0.0005 \\
(0.0006)\end{array}$ & $\begin{array}{c}0.0004 \\
(0.0006)\end{array}$ & $\begin{array}{c}0.0005 \\
(0.0006)\end{array}$ & $\begin{array}{c}0.0009 \\
(0.0008)\end{array}$ & $\begin{array}{c}0.0005 \\
(0.0007)\end{array}$ & $\begin{array}{c}0.0011 \\
(0.0008)\end{array}$ \\
\hline TEAMSIZE & $\begin{array}{c}-0.0032 \\
(0.0058)\end{array}$ & $\begin{array}{c}-0.0013 \\
(0.0054)\end{array}$ & $\begin{array}{l}-0.0014 \\
(0.0054)\end{array}$ & $\begin{array}{l}-0.0008 \\
(0.0056)\end{array}$ & $\begin{array}{l}-0.0011 \\
(0.0054)\end{array}$ & $\begin{array}{l}-0.0005 \\
(0.0056)\end{array}$ & $\begin{array}{c}0.0082 \\
(0.0068)\end{array}$ & $\begin{array}{c}-0.0018 \\
(0.0050)\end{array}$ & $\begin{array}{c}0.0061 \\
(0.0068)\end{array}$ \\
\hline EXPERIENCE & $\begin{array}{c}-0.0007^{* * * * *} \\
(0.0001)\end{array}$ & $\begin{array}{c}-0.0006^{* * * *} \\
(0.0002)\end{array}$ & $\begin{array}{c}-0.0006^{* * * * *} \\
(0.0002)\end{array}$ & $\begin{array}{c}-0.0006^{* * * * *} \\
(0.0002)\end{array}$ & $\begin{array}{c}-0.0006^{* * * * *} \\
(0.0002)\end{array}$ & $\begin{array}{c}-0.0006^{* * * * *} \\
(0.0002)\end{array}$ & $\begin{array}{c}-0.0026^{* * * *} \\
(0.0009)\end{array}$ & $\begin{array}{c}-0.00066^{* * * * *} \\
(0.0002)\end{array}$ & $\begin{array}{c}-0.0024 \\
(0.0023)\end{array}$ \\
\hline GRANTYEAR & yes & yes & yes & yes & yes & yes & yes & yes & yes \\
\hline DISTANCE & & $\begin{array}{c}0.2664^{* * * * *} \\
(0.0289)\end{array}$ & $\begin{array}{c}0.1727^{* * * * *} \\
(0.0459)\end{array}$ & $\begin{array}{c}0.2913^{* * * * *} \\
(0.0319)\end{array}$ & $\begin{array}{c}0.2401^{* * * *} \\
(0.0352)\end{array}$ & $\begin{array}{l}0.1449^{* *} \\
(0.0598)\end{array}$ & $\begin{array}{l}0.1267^{* *} \\
(0.0631)\end{array}$ & $\begin{array}{l}0.1422^{* *} \\
(0.0600)\end{array}$ & $\begin{array}{l}0.1188^{*} \\
(0.0642)\end{array}$ \\
\hline NPRS & & $\begin{array}{l}-0.0006 \\
(0.0006)\end{array}$ & $\begin{array}{l}-0.0006 \\
(0.0006)\end{array}$ & $\begin{array}{c}0.0010 \\
(0.0008)\end{array}$ & $\begin{array}{l}-0.0007 \\
(0.0005)\end{array}$ & $\begin{array}{c}0.0014^{*} \\
(0.0008)\end{array}$ & $\begin{array}{l}0.0014^{*} \\
(0.0008)\end{array}$ & $\begin{array}{c}0.0014^{*} \\
(0.0008)\end{array}$ & $\begin{array}{c}0.0014^{*} \\
(0.0008)\end{array}$ \\
\hline PRIVATE & & $\begin{array}{c}-0.0788^{* * * *} \\
(0.0289)\end{array}$ & $\begin{array}{c}-0.1214^{* * *} \\
(0.0383)\end{array}$ & $\begin{array}{c}-0.0787^{* * * *} \\
(0.0289)\end{array}$ & $\begin{array}{c}-0.0783^{* * *} \\
(0.0290)\end{array}$ & $\begin{array}{c}-0.1219^{* * *} \\
(0.0391)\end{array}$ & $\begin{array}{c}-0.1131^{* * *} \\
(0.0402)\end{array}$ & $\begin{array}{c}-0.1198^{* * * *} \\
(0.0392)\end{array}$ & $\begin{array}{c}-0.1098^{* * *} \\
(0.0405)\end{array}$ \\
\hline NANOBIO & & $\begin{array}{l}-0.0118 \\
(0.0231)\end{array}$ & $\begin{array}{c}-0.0115 \\
(0.0230)\end{array}$ & $\begin{array}{l}-0.0116 \\
(0.0230)\end{array}$ & $\begin{array}{l}-0.0376 \\
(0.0366)\end{array}$ & $\begin{array}{l}-0.0653^{*} \\
(0.0355)\end{array}$ & $\begin{array}{c}-0.0973^{\text {**** }} \\
(0.0348)\end{array}$ & $\begin{array}{l}-0.0691^{*} \\
(0.0383)\end{array}$ & $\begin{array}{c}-0.1017^{* * *} \\
(0.0367)\end{array}$ \\
\hline DISTANCExPRIVATE & & & $\begin{array}{l}0.1191^{* *} \\
(0.0527)\end{array}$ & & & $\begin{array}{l}0.1236^{* *} \\
(0.0580)\end{array}$ & $\begin{array}{c}0.1167^{*} \\
(0.0606)\end{array}$ & $\begin{array}{l}0.1257^{* *} \\
(0.0580)\end{array}$ & $\begin{array}{c}0.1164^{*} \\
(0.0623)\end{array}$ \\
\hline DISTANCExNPR & & & & $\begin{array}{c}-0.0040^{* *} \\
(0.0016)\end{array}$ & & $\begin{array}{c}-0.0049^{* * * *} \\
(0.0018)\end{array}$ & $\begin{array}{c}-0.0049^{* *} \\
(0.0019)\end{array}$ & $\begin{array}{c}-0.0050^{* * * *} \\
(0.0018)\end{array}$ & $\begin{array}{c}-0.0050^{* * * *} \\
(0.0019)\end{array}$ \\
\hline DISTANCExNANOBIO & & & & & $\begin{array}{c}0.0691 \\
(0.0607)\end{array}$ & $\begin{array}{l}0.1455^{* *} \\
(0.0620)\end{array}$ & $\begin{array}{c}0.1822^{* * *} \\
(0.0675)\end{array}$ & $\begin{array}{l}0.1456^{* *} \\
(0.0641)\end{array}$ & $\begin{array}{l}0.1828^{* *} \\
(0.0731)\end{array}$ \\
\hline Constant & $\begin{array}{c}0.2437^{\text {****** }} \\
(0.0461)\end{array}$ & $\begin{array}{c}0.2629^{* * * * *} \\
(0.0497)\end{array}$ & $\begin{array}{c}0.2978^{* * * * *} \\
(0.0542)\end{array}$ & $\begin{array}{c}0.2485^{\text {****** }} \\
(0.0491)\end{array}$ & $\begin{array}{c}0.2723^{* * * * *} \\
(0.0512)\end{array}$ & $\begin{array}{c}0.3007^{* * * * *} \\
(0.0571)\end{array}$ & $\begin{array}{c}0.3187^{* * * * *} \\
(0.0630)\end{array}$ & $\begin{array}{c}0.3157^{\text {****** }} \\
(0.0573)\end{array}$ & $\begin{array}{c}0.3395^{\text {****** }} \\
(0.0612)\end{array}$ \\
\hline Observations & 848 & 848 & 848 & 848 & 848 & 848 & 583 & 797 & 532 \\
\hline Clusters & 284 & 284 & 284 & 284 & 284 & 284 & 283 & 283 & 282 \\
\hline Log lik. & -39.4256 & -2.1288 & -0.8163 & -0.3000 & -1.4895 & 2.8897 & 14.2966 & -3.5638 & 8.3555 \\
\hline $\mathrm{F}$ & 21.2631 & 36.2711 & 33.2830 & 37.5611 & 36.0163 & 36.1487 & 14.7157 & 35.5227 & 9.4463 \\
\hline p-value & 0.0000 & 0.0000 & 0.0000 & 0.0000 & 0.0000 & 0.0000 & 0.0000 & 0.0000 & 0.0000 \\
\hline R-squared & 0.1458 & 0.2177 & 0.2201 & 0.2211 & 0.2189 & 0.2269 & 0.2197 & 0.2338 & 0.2285 \\
\hline Adjusted R-squared & 0.1325 & 0.2017 & 0.2032 & 0.2042 & 0.2019 & 0.2082 & 0.1919 & 0.2141 & 0.1983 \\
\hline
\end{tabular}

Standard errors in parentheses

${ }^{*} p<0.1,{ }^{* *} p<0.05,{ }^{* * *} p<0.01,{ }^{* * * *} p<0.001$ 
Table A.4: Results - Tobit regressions using NBPAT.

\begin{tabular}{|c|c|c|c|c|c|c|c|c|c|}
\hline & (1) & (2) & (3) & (4) & (5) & (6) & (7) & (8) & (9) \\
\hline \multicolumn{10}{|l|}{ model } \\
\hline NCITFORW & $\begin{array}{c}0.0035^{* * * * *} \\
(0.0006)\end{array}$ & $\begin{array}{c}0.0034^{* * * *} \\
(0.0005)\end{array}$ & $\begin{array}{c}0.0034^{* * * * *} \\
(0.0005)\end{array}$ & $\begin{array}{c}0.0034^{* * * *} \\
(0.0004)\end{array}$ & $\begin{array}{c}0.0033^{* * * *} \\
(0.0005)\end{array}$ & $\begin{array}{c}0.0034^{* * * *} \\
(0.0004)\end{array}$ & $\begin{array}{c}0.0035^{* * * *} \\
(0.0007)\end{array}$ & $\begin{array}{c}0.0036^{* * * *} \\
(0.0004)\end{array}$ & $\begin{array}{c}0.0039^{* * * * *} \\
(0.0007)\end{array}$ \\
\hline NCITBACK & $\begin{array}{c}0.0030^{*} \\
(0.0018)\end{array}$ & $\begin{array}{c}-0.0002 \\
(0.0018)\end{array}$ & $\begin{array}{l}-0.0004 \\
(0.0018)\end{array}$ & $\begin{array}{c}0.0004 \\
(0.0019)\end{array}$ & $\begin{array}{l}-0.0004 \\
(0.0018)\end{array}$ & $\begin{array}{c}0.0000 \\
(0.0020)\end{array}$ & $\begin{array}{l}-0.0015 \\
(0.0021)\end{array}$ & $\begin{array}{c}0.0000 \\
(0.0020)\end{array}$ & $\begin{array}{c}-0.0014 \\
(0.0021)\end{array}$ \\
\hline SCOPE & $\begin{array}{c}0.0428^{* * * *} \\
(0.0162)\end{array}$ & $\begin{array}{c}0.0270^{*} \\
(0.0145)\end{array}$ & $\begin{array}{c}0.0264^{*} \\
(0.0145)\end{array}$ & $\begin{array}{c}0.0256^{*} \\
(0.0145)\end{array}$ & $\begin{array}{l}0.0283^{* *} \\
(0.0139)\end{array}$ & $\begin{array}{l}0.0273^{* *} \\
(0.0139)\end{array}$ & $\begin{array}{c}0.0105 \\
(0.0113)\end{array}$ & $\begin{array}{c}0.0264^{*} \\
(0.0148)\end{array}$ & $\begin{array}{c}0.0081 \\
(0.0120)\end{array}$ \\
\hline CLAIMS & $\begin{array}{c}0.0004 \\
(0.0008)\end{array}$ & $\begin{array}{c}0.0007 \\
(0.0007)\end{array}$ & $\begin{array}{c}0.0007 \\
(0.0007)\end{array}$ & $\begin{array}{c}0.0007 \\
(0.0007)\end{array}$ & $\begin{array}{c}0.0006 \\
(0.0007)\end{array}$ & $\begin{array}{c}0.0007 \\
(0.0007)\end{array}$ & $\begin{array}{c}0.0011 \\
(0.0009)\end{array}$ & $\begin{array}{c}0.0008 \\
(0.0007)\end{array}$ & $\begin{array}{c}0.0014 \\
(0.0009)\end{array}$ \\
\hline TEAMSIZE & $\begin{array}{l}-0.0025 \\
(0.0066)\end{array}$ & $\begin{array}{l}-0.0009 \\
(0.0063)\end{array}$ & $\begin{array}{l}-0.0010 \\
(0.0062)\end{array}$ & $\begin{array}{c}-0.0001 \\
(0.0064)\end{array}$ & $\begin{array}{l}-0.0007 \\
(0.0063)\end{array}$ & $\begin{array}{c}0.0003 \\
(0.0064)\end{array}$ & $\begin{array}{c}0.0097 \\
(0.0075)\end{array}$ & $\begin{array}{l}-0.0008 \\
(0.0059)\end{array}$ & $\begin{array}{c}0.0080 \\
(0.0076)\end{array}$ \\
\hline NBPAT & $\begin{array}{c}-0.0004^{* * * * *} \\
(0.0001)\end{array}$ & $\begin{array}{c}-0.0004^{* * * * *} \\
(0.0001)\end{array}$ & $\begin{array}{c}-0.0004^{* * * * *} \\
(0.0001)\end{array}$ & $\begin{array}{c}-0.0004^{* * * * *} \\
(0.0001)\end{array}$ & $\begin{array}{c}-0.0004^{* * * * *} \\
(0.0001)\end{array}$ & $\begin{array}{c}-0.0004^{* * * * *} \\
(0.0001)\end{array}$ & $\begin{array}{c}-0.0015^{* *} \\
(0.0007)\end{array}$ & $\begin{array}{c}-0.0004^{* * * * *} \\
(0.0001)\end{array}$ & $\begin{array}{l}-0.0007 \\
(0.0029)\end{array}$ \\
\hline GRANTYEAR & yes & yes & yes & yes & yes & yes & yes & yes & yes \\
\hline DISTANCE & & $\begin{array}{c}0.2934^{* * * *} \\
(0.0356)\end{array}$ & $\begin{array}{c}0.1814^{* * *} \\
(0.0559)\end{array}$ & $\begin{array}{c}0.3259^{* * * * *} \\
(0.0395)\end{array}$ & $\begin{array}{c}0.2566^{* * * *} \\
(0.0410)\end{array}$ & $\begin{array}{l}0.1419^{* *} \\
(0.0718)\end{array}$ & $\begin{array}{l}0.1248^{*} \\
(0.0731)\end{array}$ & $\begin{array}{c}0.1400^{*} \\
(0.0722)\end{array}$ & $\begin{array}{c}0.1205 \\
(0.0747)\end{array}$ \\
\hline NPRS & & $\begin{array}{l}-0.0005 \\
(0.0006)\end{array}$ & $\begin{array}{l}-0.0005 \\
(0.0006)\end{array}$ & $\begin{array}{c}0.0016^{*} \\
(0.0009)\end{array}$ & $\begin{array}{l}-0.0005 \\
(0.0006)\end{array}$ & $\begin{array}{l}0.0022^{* *} \\
(0.0010)\end{array}$ & $\begin{array}{l}0.0019^{* *} \\
(0.0010)\end{array}$ & $\begin{array}{l}0.0022^{* *} \\
(0.0010)\end{array}$ & $\begin{array}{l}0.0020^{* *} \\
(0.0010)\end{array}$ \\
\hline PRIVATE & & $\begin{array}{c}-0.0882^{* *} \\
(0.0347)\end{array}$ & $\begin{array}{c}-0.1401^{* * * *} \\
(0.0475)\end{array}$ & $\begin{array}{l}-0.0881^{* *} \\
(0.0346)\end{array}$ & $\begin{array}{l}-0.0877^{* * *} \\
(0.0347)\end{array}$ & $\begin{array}{c}-0.1418^{* * * *} \\
(0.0489)\end{array}$ & $\begin{array}{c}-0.1330^{* * * *} \\
(0.0488)\end{array}$ & $\begin{array}{c}-0.1400^{* * * *} \\
(0.0493)\end{array}$ & $\begin{array}{c}-0.1304^{* *} \\
(0.0506)\end{array}$ \\
\hline NANOBIO & & $\begin{array}{l}-0.0249 \\
(0.0281)\end{array}$ & $\begin{array}{c}-0.0245 \\
(0.0280)\end{array}$ & $\begin{array}{c}-0.0246 \\
(0.0278)\end{array}$ & $\begin{array}{l}-0.0613 \\
(0.0468)\end{array}$ & $\begin{array}{c}-0.0987^{* * *} \\
(0.0455)\end{array}$ & $\begin{array}{c}-0.1317^{\text {***** }} \\
(0.0435)\end{array}$ & $\begin{array}{c}-0.1026^{* *} \\
(0.0485)\end{array}$ & $\begin{array}{c}-0.1353^{* * *} \\
(0.0454)\end{array}$ \\
\hline DISTANCExPRIVATE & & & $\begin{array}{l}0.1434^{* *} \\
(0.0641)\end{array}$ & & & $\begin{array}{l}0.1508^{* *} \\
(0.0713)\end{array}$ & $\begin{array}{l}0.1436^{* *} \\
(0.0725)\end{array}$ & $\begin{array}{l}0.1528^{* *} \\
(0.0716)\end{array}$ & $\begin{array}{c}0.1427^{*} \\
(0.0753)\end{array}$ \\
\hline DISTANCExNPR & & & & $\begin{array}{c}-0.0051^{* * *} \\
(0.0020)\end{array}$ & & $\begin{array}{c}-0.0066^{* * * *} \\
(0.0023)\end{array}$ & $\begin{array}{c}-0.0060^{* * * *} \\
(0.0023)\end{array}$ & $\begin{array}{c}-0.0067^{* * * *} \\
(0.0023)\end{array}$ & $\begin{array}{c}-0.0064^{* * * *} \\
(0.0023)\end{array}$ \\
\hline DISTANCExNANOBIO & & & & & $\begin{array}{c}0.0960 \\
(0.0772)\end{array}$ & $\begin{array}{l}0.1968^{* *} \\
(0.0787)\end{array}$ & $\begin{array}{c}0.2360^{* * * *} \\
(0.0810)\end{array}$ & $\begin{array}{l}0.1963^{* *} \\
(0.0814)\end{array}$ & $\begin{array}{c}0.2398^{\text {**** }} \\
(0.0881)\end{array}$ \\
\hline Constant & $\begin{array}{c}0.1996^{\text {******* }} \\
(0.0555)\end{array}$ & $\begin{array}{c}0.2242^{* * * * *} \\
(0.0616)\end{array}$ & $\begin{array}{c}0.2659^{* * * * *} \\
(0.0671)\end{array}$ & $\begin{array}{c}0.2050^{* * * * *} \\
(0.0615)\end{array}$ & $\begin{array}{c}0.2380^{* * * * *} \\
(0.0630)\end{array}$ & $\begin{array}{c}0.2718^{* * * * *} \\
(0.0709)\end{array}$ & $\begin{array}{c}0.2924^{* * * * *} \\
(0.0782)\end{array}$ & $\begin{array}{c}0.2905^{* * * * *} \\
(0.0708)\end{array}$ & $\begin{array}{c}0.3066^{* * * * * *} \\
(0.0750)\end{array}$ \\
\hline \multicolumn{10}{|l|}{ sigma } \\
\hline Constant & $\begin{array}{c}0.3034^{* * * * *} \\
(0.0112)\end{array}$ & $\begin{array}{c}0.2909^{* * * *} \\
(0.0116)\end{array}$ & $\begin{array}{c}0.2904^{* * * * *} \\
(0.0118)\end{array}$ & $\begin{array}{c}0.2901^{* * * * *} \\
(0.0117)\end{array}$ & $\begin{array}{c}0.2907^{* * * * *} \\
(0.0117)\end{array}$ & $\begin{array}{c}0.2890^{* * * * *} \\
(0.0120)\end{array}$ & $\begin{array}{c}0.2753^{* * * *} \\
(0.0129)\end{array}$ & $\begin{array}{c}0.2929^{* * * * *} \\
(0.0115)\end{array}$ & $\begin{array}{c}0.2800^{\text {****** }} \\
(0.0132)\end{array}$ \\
\hline Observations & 848 & 848 & 848 & 848 & 848 & 848 & 583 & 797 & 532 \\
\hline Clusters & 284 & 284 & 284 & 284 & 284 & 284 & 283 & 283 & 282 \\
\hline Log lik. & -332.9313 & -302.2670 & -300.9739 & -300.1840 & -301.4383 & -296.5088 & -172.2752 & -290.3013 & -167.1253 \\
\hline $\mathrm{F}$ & 17.6609 & 30.7631 & 28.7567 & 32.2992 & 30.0669 & 31.1296 & 10.5480 & 30.2262 & 7.0043 \\
\hline $\mathrm{p}$-value & 0.0000 & 0.0000 & 0.0000 & 0.0000 & 0.0000 & 0.0000 & 0.0000 & 0.0000 & 0.0000 \\
\hline pseudo R-squared & 0.1676 & 0.2443 & 0.2475 & 0.2495 & 0.2464 & 0.2587 & 0.2912 & 0.2571 & 0.2858 \\
\hline
\end{tabular}

${ }^{*} p<0.1,{ }^{* *} p<0.05,{ }^{* * *} p<0.01,{ }^{* * * *} p<0.001$ 
Table A.5: Results - Tobit regressions using EXPERIENCE.

\begin{tabular}{|c|c|c|c|c|c|c|c|c|c|}
\hline & (1) & (2) & (3) & (4) & (5) & (6) & (7) & (8) & (9) \\
\hline \multicolumn{10}{|l|}{ model } \\
\hline NCITFORW & $\begin{array}{c}0.0035^{* * * * *} \\
(0.0005)\end{array}$ & $\begin{array}{c}0.0034^{* * * * *} \\
(0.0004)\end{array}$ & $\begin{array}{c}0.0034^{* * * * *} \\
(0.0004)\end{array}$ & $\begin{array}{c}0.0035^{* * * * *} \\
(0.0004)\end{array}$ & $\begin{array}{c}0.0033^{* * * * *} \\
(0.0004)\end{array}$ & $\begin{array}{c}0.0034^{* * * * *} \\
(0.0004)\end{array}$ & $\begin{array}{c}0.0034^{* * * *} \\
(0.0007)\end{array}$ & $\begin{array}{c}0.0036^{* * * *} \\
(0.0004)\end{array}$ & $\begin{array}{c}0.0039^{* * * * *} \\
(0.0007)\end{array}$ \\
\hline NCITBACK & $\begin{array}{c}0.0026 \\
(0.0017)\end{array}$ & $\begin{array}{c}-0.0005 \\
(0.0017)\end{array}$ & $\begin{array}{l}-0.0007 \\
(0.0018)\end{array}$ & $\begin{array}{c}0.0001 \\
(0.0018)\end{array}$ & $\begin{array}{l}-0.0007 \\
(0.0018)\end{array}$ & $\begin{array}{l}-0.0003 \\
(0.0019)\end{array}$ & $\begin{array}{l}-0.0015 \\
(0.0021)\end{array}$ & $\begin{array}{l}-0.0003 \\
(0.0020)\end{array}$ & $\begin{array}{c}-0.0014 \\
(0.0021)\end{array}$ \\
\hline SCOPE & $\begin{array}{c}0.0446^{* * *} \\
(0.0165)\end{array}$ & $\begin{array}{l}0.0270^{*} \\
(0.0143)\end{array}$ & $\begin{array}{c}0.0265^{*} \\
(0.0143)\end{array}$ & $\begin{array}{l}0.0257^{*} \\
(0.0143)\end{array}$ & $\begin{array}{l}0.0284^{* *} \\
(0.0137)\end{array}$ & $\begin{array}{l}0.0275^{* *} \\
(0.0136)\end{array}$ & $\begin{array}{c}0.0109 \\
(0.0113)\end{array}$ & $\begin{array}{c}0.0267^{*} \\
(0.0146)\end{array}$ & $\begin{array}{c}0.0084 \\
(0.0120)\end{array}$ \\
\hline CLAIMS & $\begin{array}{c}0.0002 \\
(0.0009)\end{array}$ & $\begin{array}{c}0.0006 \\
(0.0007)\end{array}$ & $\begin{array}{c}0.0006 \\
(0.0007)\end{array}$ & $\begin{array}{c}0.0006 \\
(0.0007)\end{array}$ & $\begin{array}{c}0.0005 \\
(0.0007)\end{array}$ & $\begin{array}{c}0.0006 \\
(0.0007)\end{array}$ & $\begin{array}{c}0.0011 \\
(0.0009)\end{array}$ & $\begin{array}{c}0.0007 \\
(0.0008)\end{array}$ & $\begin{array}{c}0.0014 \\
(0.0009)\end{array}$ \\
\hline TEAMSIZE & $\begin{array}{c}-0.0032 \\
(0.0066)\end{array}$ & $\begin{array}{c}-0.0008 \\
(0.0061)\end{array}$ & $\begin{array}{c}-0.0009 \\
(0.0060)\end{array}$ & $\begin{array}{c}-0.0002 \\
(0.0062)\end{array}$ & $\begin{array}{l}-0.0006 \\
(0.0061)\end{array}$ & $\begin{array}{c}0.0004 \\
(0.0062)\end{array}$ & $\begin{array}{c}0.0101 \\
(0.0076)\end{array}$ & $\begin{array}{l}-0.0008 \\
(0.0057)\end{array}$ & $\begin{array}{c}0.0081 \\
(0.0078)\end{array}$ \\
\hline EXPERIENCE & $\begin{array}{c}-0.0008^{* * * * *} \\
(0.0001)\end{array}$ & $\begin{array}{c}-0.0007^{* * * * *} \\
(0.0002)\end{array}$ & $\begin{array}{c}-0.0007^{* * * * *} \\
(0.0002)\end{array}$ & $\begin{array}{c}-0.0007^{* * * * *} \\
(0.0002)\end{array}$ & $\begin{array}{c}-0.0008^{* * * * *} \\
(0.0002)\end{array}$ & $\begin{array}{c}-0.0008^{* * * * *} \\
(0.0002)\end{array}$ & $\begin{array}{c}-0.0024^{* *} \\
(0.0010)\end{array}$ & $\begin{array}{c}-0.0008^{* * * *} \\
(0.0002)\end{array}$ & $\begin{array}{c}-0.0019 \\
(0.0025)\end{array}$ \\
\hline GRANTYEAR & yes & yes & yes & yes & yes & yes & yes & yes & yes \\
\hline DISTANCE & & $\begin{array}{c}0.3017^{* * * *} \\
(0.0351)\end{array}$ & $\begin{array}{c}0.1899^{* * * * *} \\
(0.0550)\end{array}$ & $\begin{array}{c}0.3334^{* * * *} \\
(0.0386)\end{array}$ & $\begin{array}{c}0.2631^{* * * *} \\
(0.0419)\end{array}$ & $\begin{array}{l}0.1469^{* *} \\
(0.0714)\end{array}$ & $\begin{array}{l}0.1248^{*} \\
(0.0733)\end{array}$ & $\begin{array}{l}0.1462^{* *} \\
(0.0718)\end{array}$ & $\begin{array}{c}0.1191 \\
(0.0749)\end{array}$ \\
\hline NPRS & & $\begin{array}{c}-0.0006 \\
(0.0006)\end{array}$ & $\begin{array}{l}-0.0006 \\
(0.0006)\end{array}$ & $\begin{array}{c}0.0015^{*} \\
(0.0009)\end{array}$ & $\begin{array}{l}-0.0006 \\
(0.0006)\end{array}$ & $\begin{array}{l}0.0020^{* *} \\
(0.0009)\end{array}$ & $\begin{array}{l}0.0019^{* *} \\
(0.0010)\end{array}$ & $\begin{array}{l}0.0020^{* *} \\
(0.0010)\end{array}$ & $\begin{array}{l}0.0020^{* *} \\
(0.0010)\end{array}$ \\
\hline PRIVATE & & $\begin{array}{c}-0.0918^{* * * *} \\
(0.0341)\end{array}$ & $\begin{array}{c}-0.1434^{* * * *} \\
(0.0469)\end{array}$ & $\begin{array}{c}-0.0919^{* * * *} \\
(0.0341)\end{array}$ & $\begin{array}{c}-0.0914^{* * * *} \\
(0.0341)\end{array}$ & $\begin{array}{c}-0.1462^{* * * *} \\
(0.0481)\end{array}$ & $\begin{array}{c}-0.1342^{* * * *} \\
(0.0485)\end{array}$ & $\begin{array}{c}-0.1458^{* * * *} \\
(0.0485)\end{array}$ & $\begin{array}{r}-0.1308^{* * * *} \\
(0.0491)\end{array}$ \\
\hline NANOBIO & & $\begin{array}{c}-0.0215 \\
(0.0278)\end{array}$ & $\begin{array}{c}-0.0213 \\
(0.0277)\end{array}$ & $\begin{array}{l}-0.0209 \\
(0.0277)\end{array}$ & $\begin{array}{c}-0.0598 \\
(0.0466)\end{array}$ & $\begin{array}{c}-0.0967^{* * *} \\
(0.0453)\end{array}$ & $\begin{array}{c}-0.1316^{* * * *} \\
(0.0436)\end{array}$ & $\begin{array}{c}-0.0987^{* * *} \\
(0.0484)\end{array}$ & $\begin{array}{c}-0.1365^{\text {**** }} \\
(0.0456)\end{array}$ \\
\hline DISTANCExPRIVATE & & & $\begin{array}{l}0.1428^{* * *} \\
(0.0639)\end{array}$ & & & $\begin{array}{l}0.1524^{* *} \\
(0.0706)\end{array}$ & $\begin{array}{l}0.1440^{* *} \\
(0.0729)\end{array}$ & $\begin{array}{l}0.1554^{* *} \\
(0.0709)\end{array}$ & $\begin{array}{l}0.1435^{*} \\
(0.0752)\end{array}$ \\
\hline DISTANCExNPR & & & & $\begin{array}{c}-0.0050^{* *} \\
(0.0020)\end{array}$ & & $\begin{array}{c}-0.0065^{* * *} \\
(0.0023)\end{array}$ & $\begin{array}{c}-0.0061^{\text {***** }} \\
(0.0023)\end{array}$ & $\begin{array}{c}-0.0066^{* * * *} \\
(0.0023)\end{array}$ & $\begin{array}{c}-0.0063^{* * * *} \\
(0.0023)\end{array}$ \\
\hline DISTANCExNANOBIO & & & & & $\begin{array}{c}0.1011 \\
(0.0758)\end{array}$ & $\begin{array}{l}0.2010^{* * * *} \\
(0.0776)\end{array}$ & $\begin{array}{c}0.2407^{* * * *} \\
(0.0819)\end{array}$ & $\begin{array}{l}0.1994^{* *} \\
(0.0801)\end{array}$ & $\begin{array}{c}0.2412^{* * * *} \\
(0.0881)\end{array}$ \\
\hline Constant & $\begin{array}{c}0.1735^{* * *} \\
(0.0610)\end{array}$ & $\begin{array}{c}0.2023^{* * * *} \\
(0.0631)\end{array}$ & $\begin{array}{c}0.2443^{* * * * *} \\
(0.0685)\end{array}$ & $\begin{array}{c}0.1837^{* * * *} \\
(0.0623)\end{array}$ & $\begin{array}{c}0.2163^{* * *} \\
(0.0657)\end{array}$ & $\begin{array}{c}0.2508^{* * * * *} \\
(0.0729)\end{array}$ & $\begin{array}{c}0.2782^{* * * * *} \\
(0.0782)\end{array}$ & $\begin{array}{c}0.2682^{* * * * *} \\
(0.0738)\end{array}$ & $\begin{array}{c}0.3031^{* * * * *} \\
(0.0762)\end{array}$ \\
\hline \multicolumn{10}{|l|}{ sigma } \\
\hline Constant & $\begin{array}{c}0.3037^{* * * *} \\
(0.0112)\end{array}$ & $\begin{array}{c}0.2904^{* * * *} \\
(0.0115)\end{array}$ & $\begin{array}{c}0.2899^{* * * *} \\
(0.0116)\end{array}$ & $\begin{array}{c}0.2897^{* * * * *} \\
(0.0116)\end{array}$ & $\begin{array}{c}0.2902^{* * * * *} \\
(0.0115)\end{array}$ & $\begin{array}{c}0.2885^{* * * *} \\
(0.0118)\end{array}$ & $\begin{array}{c}0.2757^{* * * *} \\
(0.0128)\end{array}$ & $\begin{array}{c}0.2926^{* * * * *} \\
(0.0113)\end{array}$ & $\begin{array}{c}0.2800^{\text {****** }} \\
(0.0132)\end{array}$ \\
\hline Observations & 848 & 848 & 848 & 848 & 848 & 848 & 583 & 797 & 532 \\
\hline Clusters & 284 & 284 & 284 & 284 & 284 & 284 & 283 & 283 & 282 \\
\hline Log lik. & -333.9356 & -301.1838 & -299.8981 & -299.2148 & -300.2635 & -295.3960 & -172.9004 & -289.6424 & -167.0619 \\
\hline $\mathrm{F}$ & 21.8147 & 34.3091 & 32.1643 & 35.9751 & 33.8361 & 35.2016 & 12.3492 & 34.9323 & 7.3116 \\
\hline p-value & 0.0000 & 0.0000 & 0.0000 & 0.0000 & 0.0000 & 0.0000 & 0.0000 & 0.0000 & 0.0000 \\
\hline pseudo R-squared & 0.1651 & 0.2470 & 0.2502 & 0.2519 & 0.2493 & 0.2615 & 0.2887 & 0.2588 & 0.2861 \\
\hline
\end{tabular}


Allison, J., Lemley, M., Moore, K., Trunkey, R., 2004. Valuable patents. Georgetown Law Journal 92 (3), 435-479.

Amin, A., Cohendet, P., 2004. Architectures of Knowledge: Firms, Capabilities, and Communities. Oxford University Press, USA.

Anderson, P., Tushman, M. L., 1990. Technological discontinuities and dominant designs: A cyclical model of technological change. Administrative science quarterly, 604-633.

Ankrah, S., Burgess, T., Grimshaw, P., Shaw, N., 2013. Asking both university and industry actors about their engagement in knowledge transfer: What singlegroup studies of motives omit. Technovation 33 (2), 50-65.

Archibugi, D., Pianta, M., 1996. Measuring technological change through patents and innovation surveys. Technovation 16 (9), 451-468.

Arora, A., Fosfuri, A., Gambardella, A., 2001. Markets for technology and their implications for corporate strategy. Industrial and corporate change 10 (2), 419451.

Arrow, K., 1962. Economic welfare and the allocation of resources for invention. In: The Rate and Direction of Inventive Activity: Economic and Social Factors. National Bureau of Economic Research, Inc, pp. 609-626.

Azagra-Caro, J., Mattsson, P., Perruchas, F., 2011. Smoothing the lies: The distinctive effects of patent characteristics on examiner and applicant citations. Journal of the American Society for Information Science and Technology $62(9), 1727-1740$. 
Banerjee, P. M., Cole, B. M., 2010. Breadth-of-impact frontier: How firm-level decisions and selection environment dynamics generate boundary-spanning inventions. Technovation 30 (7), 411-419.

Barirani, A., Agard, B., Beaudry, C., 2013. Discovering and assessing fields of expertise in nanomedicine: a patent co-citation network perspective. Scientometrics 94 (3), 1111-1136.

Baron, J., Delcamp, H., 2012. The private and social value of patents in discrete and cumulative innovation. Scientometrics 90 (2), 581-606.

Basberg, B., 1987. Patents and the measurement of technological change: A survey of the literature. Research Policy 16 (2-4), 131-141.

Bessen, J., 2008. The value of u.s. patents by owner and patent characteristics. Research Policy 37 (5), 932-945.

Bodas Freitas, I. M., Nuvolari, A., 2012. Traditional versus heterodox motives for academic patenting: Evidence from the netherlands. Industry \& Innovation 19 (8), 671-695.

Boschma, R., 2005. Proximity and innovation: A critical assessment. Regional Studies 39 (1), 61-74.

Callaert, J., Van Looy, B., Verbeek, A., Debackere, K., Thijs, B., 2006. Traces of prior art: An analysis of non-patent references found in patent documents. Scientometrics 69 (1), 3-20.

Cantwell, J., 2000. Technological lock-in of large firms since the interwar period. European Review of Economic History 4 (2), 147-174. 
Cockburn, I. M., Kortum, S., Stern, S., 2002. Are all patent examiners equal? the impact of examiner characteristics. Working Paper 8980, National Bureau of Economic Research.

Cohen, W., Nelson, R., Walsh, J., 2002. Links and impacts: The influence of public research on industrial r\&d. Management Science 48 (1), 1-23.

Cohen, W. M., Levinthal, D. A., 1989. Innovation and learning: The two faces of r\&d. Economic Journal 99 (397), 569-96.

Cohen, W. M., Levinthal, D. A., 1990. Absorptive capacity: a new perspective on learning and innovation. Administrative Sciences Quarterly 35 (1), 128-152.

Colyvas, J., Crow, M., Gelijns, A., Mazzoleni, R., Nelson, R., Rosenberg, N., Sampat, B., 2002. How do university inventions get into practice? Management Science 48 (1), 61-72.

Criscuolo, P., Verspagen, B., 2008. Does it matter where patent citations come from? inventor vs. examiner citations in european patents. Research Policy 37 (10), 1892-1908.

Cyert, R. M., March, J. G., 1963. A behavioral theory of the firm. Wiley.

Czarnitzki, D., Hussinger, K., Schneider, C., 2011. Commercializing academic research: the quality of faculty patenting. Industrial and Corporate Change 20 (5), $1403-1437$.

Czarnitzki, D., Hussinger, K., Schneider, C., 2012. The nexus between science and industry: evidence from faculty inventions. The Journal of Technology Transfer 37 (5), 755-776. 
D'Amore, R., Iorio, R., Labory, S., Stawinoga, A., 2013. Research collaboration networks in biotechnology: Exploring the trade-off between institutional and geographic distances. Industry and Innovation 20 (3), 261-276.

Dasgupta, P., David, P., 1994. Toward a new economics of science. Research Policy $23(5), 487-521$.

Datta, A., Jessup, L. M., 2013. Looking beyond the focal industry and existing technologies for radical innovations. Technovation 33 (10), 355-367.

David, P. A., 2004. Can "open science" be protected from the evolving regime of ipr protections? Journal of Institutional and Theoretical Economics (JITE)/Zeitschrift für die gesamte Staatswissenschaft, 9-34.

Day, G. S., 1994. The capabilities of market-driven organizations. Journal of Marketing 58 (4), 37-52.

Debackere, K., Veugelers, R., 2005. The role of academic technology transfer organizations in improving industry science links. Research Policy 34 (3), 321342.

D'Este, P., Patel, P., 2007. University-industry linkages in the uk: What are the factors underlying the variety of interactions with industry? Research Policy 36 (9), 1295-1313.

Dosi, G., 1982. Technological paradigms and technological trajectories. a suggested interpretation of the determinants and directions of technical change. Research Policy 11 (3), 147-162. 
Dosi, G., 1988. Sources, procedures, and microeconomic effects of innovation. Journal of economic literature, 1120-1171.

Etzkowitz, H., 1998. The norms of entrepreneurial science: cognitive effects of the new university-industry linkages. Research policy 27 (8), 823-833.

Etzkowitz, H., 2003. Research groups as 'quasi-firms': The invention of the entrepreneurial university. Research Policy 32 (1), 109-121.

Fang, C., Lee, J., Schilling, M., 2010. Balancing exploration and exploitation through structural design: The isolation of subgroups and organizational learning. Organization Science 21 (3), 625-642.

Fischer, T., Leidinger, J., 2014. Testing patent value indicators on directly observed patent value - an empirical analysis of ocean tomo patent auctions. Research Policy 43 (3).

Fleming, L., 2001. Recombinant uncertainty in technological search. Management Science 47 (1), 117-132.

Fleming, L., Sorenson, O., 2001. Technology as a complex adaptive system: Evidence from patent data. Research Policy 30 (7), 1019-1039.

Foray, D., Lissoni, F., 2010. University research and public-private interaction. In: Hall, B. H., Rosenberg, N. (Eds.), Handbook of The Economics of Innovation. Elsevier, pp. 275-314.

Geroski, P., 2000. Models of technology diffusion. Research Policy 29 (4-5), 603625. 
Gilsing, V., Bekkers, R., Bodas Freitas, I. M., van der Steen, M., 2011. Differences in technology transfer between science-based and development-based industries: Transfer mechanisms and barriers. Technovation 31 (12), 638-647.

Gittelman, M., Kogut, B., 2003. Does good science lead to valuable knowledge? biotechnology firms and the evolutionary logic of citation patterns. Management Science 49 (4), 366-382.

Gómez-Baquero, F., 2009. Measuring the generality of nanotechnologies and its potential economic implications. In: Science and Innovation Policy, 2009 Atlanta Conference on. pp. 1-9.

Griffin, A., Hauser, J. R., 1996. Integrating r\&d and marketing: a review and analysis of the literature. Journal of product innovation management 13 (3), 191-215.

Griliches, Z., 1990. Patent statistics as economic indicators: A survey. Journal of Economic Literature 28 (4), 1661-1707.

Grimpe, C., Hussinger, K., 2013. Formal and informal knowledge and technology transfer from academia to industry: Complementarity effects and innovation performance. Industry and Innovation 20 (8), 683-700.

Gruber, M., Harhoff, D., Hoisl, K., 2013. Knowledge recombination across technological boundaries: Scientists versus engineers. Management Science 59 (4), 837-851.

Hair, J. F., Black, W. C., Babin, B. J., Anderson, R. E., 2009. Multivariate Data Analysis, 7th Edition. Prentice Hall. 
Hall, B., Jaffe, A., Trajtenberg, M., 2005. Market value and patent citations. RAND Journal of Economics 36 (1), 16-38.

Hegde, D., Sampat, B., 2009. Examiner citations, applicant citations, and the private value of patents. Economics Letters 105 (3), 287-289.

Henderson, R., Jaffe, A., Trajtenberg, M., 1998. Universities as a source of commercial technology: A detailed analysis of university patenting, 1965-1988. Review of Economics and Statistics 80 (1), 119-127.

Jaffe, A., 1989. Real effects of academic research. American Economic Review $79(5), 957-70$.

Jaffe, A., Trajtenberg, M., Henderson, R., 1993. Geographic localization of knowledge spillovers as evidenced by patent citations. Quarterly Journal of Economics 108 (3), 577-598.

Jensen, R., Thursby, M., 2001. Proofs and prototypes for sale: The licensing of university inventions. American Economic Review 91 (1), 240-259.

Kenney, M., Patton, D., 2009. Reconsidering the bayh-dole act and the current university invention ownership model. Research Policy 38 (9), 1407-1422.

Kim, C., Song, J., Nerkar, A., 2012. Learning and innovation: Exploitation and exploration trade-offs. Journal of Business Research 65 (8), 1189-1194.

Krugman, P., 1991. Increasing returns and economic geography. Journal of Political Economy 99 (3), 483-499.

Landry, R., Amara, N., Cloutier, J.-S., Halilem, N., 2013. Technology transfer organizations: Services and business models. Technovation 33 (12), 431-449. 
Lanjouw, J., Schankerman, M., 2004. Protecting intellectual property rights: Are small firms handicapped? Journal of Law and Economics 47 (1), 45-74.

Larsen, M. T., 2011. The implications of academic enterprise for public science: An overview of the empirical evidence. Research Policy 40 (1), 6-19.

Laursen, K., Leone, M. I., Torrisi, S., 2010. Technological exploration through licensing: New insights from the licensee's point of view. Industrial and Corporate Change 19 (3), 871-897.

Leenders, M. A., Wierenga, B., 2002. The effectiveness of different mechanisms for integrating marketing and $\mathrm{r} \& \mathrm{~d}$. Journal of Product Innovation Management 19 (4), 305-317.

Lemley, M., Shapiro, C., 2005. Probabilistic patents. Journal of Economic Perspectives 19 (2), 75-98.

Lerner, J., 1994. The importance of patent scope: An empirical analysis. The RAND Journal of Economics 25 (2), 319-333.

Levinthal, D. A., March, J. G., 1993. The myopia of learning. Strategic Management Journal 14 (S2), 95-112.

Levitt, B., March, J., 1988. Organizational learning. Annual Review of Sociology 14, 319-340.

Li, X., Lin, Y., Chen, H., Roco, M., 2007. Worldwide nanotechnology development: A comparative study of uspto, epo, and jpo patents (1976-2004). Journal of Nanoparticle Research 9 (6), 977-1002. 
Lissoni, F., 2012. Academic patenting in europe: An overview of recent research and new perspectives. World Patent Information 34 (3), 197-205.

Lo, C.-C., Wang, C.-H., Chien, P.-Y., Hung, C.-W., 2012. An empirical study of commercialization performance on nanoproducts. Technovation 32 (3-4), 168178.

Lynn, G., Morone, J., Paulson, A., 1996. Marketing and discontinuous innovation: the probe and learn process. California management review 38 (3).

Maine, E., Thomas, V., Utterback, J., 2014. Radical innovation from the confluence of technologies: Innovation management strategies for the emerging nanobiotechnology industry. Journal of Engineering and Technology Management 32, 1-25.

March, J., 1991. Exploration and exploitation in organizational learning. Organization Science 2 (1), 71-87.

March, J., Simon, H., 1958. Organizations. Wiley.

McGrath, R., 2001. Exploratory learning, innovative capacity, and managerial oversight. Academy of Management Journal 44 (1), 118-131.

Merges, R., Nelson, R., 1990. On the complex economics of patent scope. Columbia Law Review 90 (4), 839-916.

Meyer, M., 2000. What is special about patent citations? differences between scientific and patent citations. Scientometrics 49 (1), 93-123.

Moore, K. A., 2005. Worthless patents. Berkeley Technology Law Journal 20 (4), $1521-1552$. 
Mowery, D., Sampat, B., Ziedonis, A., 2002. Learning to patent: Institutional experience, learning, and the characteristics of u.s. university patents after the bayh-dole act, 1981-1992. Management Science 48 (1), 73-89.

Mowery, D. C., Sampat, B. N., 2005. The bayh-dole act of 1980 and universityindustry technology transfer: a model for other oecd governments? In: Link, A. N., Scherer, F. M. (Eds.), Essays in honor of Edwin Mansfield. Springer, pp. 233-245.

Mowery, D. C., Ziedonis, A. A., 2002. Academic patent quality and quantity before and after the bayh-dole act in the united states. Research Policy 31 (3), 399-418.

Muscio, A., Pozzali, A., 2013. The effects of cognitive distance in universityindustry collaborations: some evidence from italian universities. The Journal of Technology Transfer 38 (4), 486-508.

Narin, F., Hamilton, K., Olivastro, D., 1997. The increasing linkage between u.s. technology and public science. Research Policy 26 (3), 317-330.

Nelson, R., Winter, S., 1982. An Evolutionary Theory of Economic Change. Belknap Press of Harvard University Press.

Nelson, R. R., 1959. The simple economics of basic scientific research. Journal of Political Economy 67 (3), 297-306.

Nemet, G., Johnson, E., 2012. Do important inventions benefit from knowledge originating in other technological domains? Research Policy 41 (1), 190-200. 
Neter, J., Wasserman, W., Kutner, M., 1985. Applied linear statistical models: regression, analysis of variance, and experimental designs. R.D. Irwin.

Nikulainen, T., Palmberg, C., 2010. Transferring science-based technologies to industry — does nanotechnology make a difference? Technovation 30 (1), 3-11.

Nooteboom, B., Van Haverbeke, W., Duysters, G., Gilsing, V., van den Oord, A., 2007. Optimal cognitive distance and absorptive capacity. Research Policy 36 (7), 1016-1034.

Owen-Smith, J., Powell, W., 2004. Knowledge networks as channels and conduits: The effects of spillovers in the boston biotechnology community. Organization Science 15 (1), 5-21.

Petruzzelli, A. M., 2011. The impact of technological relatedness, prior ties, and geographical distance on university-industry collaborations: A joint-patent analysis. Technovation 31 (7), 309-319.

Philpott, K., Dooley, L., O’Reilly, C., Lupton, G., 2011. The entrepreneurial university: Examining the underlying academic tensions. Technovation 31 (4), $161-170$.

Pénin, J., 2005. Patents versus ex post rewards: A new look. Research Policy $34(5), 641-656$.

Raisch, S., Birkinshaw, J., Probst, G., Tushman, M., 2009. Organizational ambidexterity: Balancing exploitation and exploration for sustained performance. Organization Science 20 (4), 685-695. 
Rogers, W., 1987. Regression standard errors in clustered samples. Stata technical bulletin 3 (13).

Rosenberg, N., 1994. Exploring the Black Box: Technology, Economics, and History. Cambridge University Press.

Rosenkopf, L., Nerkar, A., 2001. Beyond local search: Boundary-spanning, exploration, and impact in the optical disk industry. Strategic Management Journal $22(4), 287-306$.

Sampat, B., 2010. When do applicants search for prior art? Journal of Law and Economics 53 (2), 399-416.

Sapsalis, E., van Pottelsberghe de la Potterie, B., Navon, R., 2006. Academic versus industry patenting: An in-depth analysis of what determines patent value. Research Policy 35 (10), 1631-1645.

Schoenmakers, W., Duysters, G., 2010. The technological origins of radical inventions. Research Policy 39 (8), 1051-1059.

Schumpeter, J., 1934. The Theory of Economic Development: An Inquiry Into Profits, Capital, Credit, Interest, and the Business Cycle. Transaction Books.

Serrano, C. J., 2010. The dynamics of the transfer and renewal of patents. The RAND Journal of Economics 41 (4), 686-708.

Shane, S., 2004a. Academic entrepreneurship. Edward Elgar Publishing.

Shane, S., 2004b. Encouraging university entrepreneurship? the effect of the bayh-dole act on university patenting in the united states. Journal of Business Venturing 19 (1), 127-151. 
Shea, C. M., Grinde, R., Elmslie, B., 2011. Nanotechnology as general-purpose technology: empirical evidence and implications. Technology Analysis \& Strategic Management 23 (2), 175-192.

Silverberg, G., Dosi, G., Orsenigo, L., 1988. Innovation, diversity and diffusion: a self-organisation model. The Economic Journal 98 (393), 1032-1054.

Squicciarini, M., Dernis, H., Criscuolo, C., 2013. Measuring patent quality: Indicators of technological and economic value. Tech. rep., OECD Publishing.

Sreekumaran Nair, S., Mathew, M., Nag, D., 2011. Dynamics between patent latent variables and patent price. Technovation 31 (12), 648-654.

Stephan, P. E., 1996. The economics of science. Journal of Economic Literature 34 (3), 1199-1235.

Tartari, V., Breschi, S., 2012. Set them free: scientists' evaluations of the benefits and costs of university-industry research collaboration. Industrial and Corporate Change 21 (5), 1117-1147.

Teece, D., 1986. Profiting from technological innovation: Implications for integration, collaboration, licensing and public policy. Research Policy 15 (6), 285-305.

Teece, D. J., 1998. Capturing value from knowledge assets: the new economy, markets for know-how and intangible assets. California Management Review 40 (3), 55-79.

Teece, D. J., 2007. Explicating dynamic capabilities: the nature and microfoun- 
dations of (sustainable) enterprise performance. Strategic management journal 28 (13), 1319-1350.

Thursby, J., Thursby, M., 2007. University licensing. Oxford Review of Economic Policy 23 (4), 620-639.

Tong, X., Frame, J., 1994. Measuring national technological performance with patent claims data. Research Policy 23 (2), 133-141.

Trajtenberg, M., 1990. A penny for your quotes: Patent citations and the value of innovations. RAND Journal of Economics 21 (1), 172-187.

Trajtenberg, M. R., Henderson, R., Jaffe, A. B., 1997. University versus corporate patents: a window on the basicness of invention. Economics of Innovation and New Technologies 5 (19), 19-50.

Tripsas, M., 1997. Unraveling the process of creative destruction: Complementary assets and incumbent survival in the typesetter industry. Strategic Management Journal 18 (SPEC. ISS.), 119-142.

Tushman, M., O’Reilly III, C., 1996. Ambidextrous organizations: Managing evolutionary and revolutionary change. California Management Review 38 (4), 830.

Tushman, M. L., Anderson, P., 1986. Technological discontinuities and organizational environments. Administrative science quarterly, 439-465.

Utterback, J., Suárez, F., 1993. Innovation, competition, and industry structure. Research Policy 22 (1), 1-21. 
Utterback, J. M., Abernathy, W. J., 1975. A dynamic model of process and product innovation. Omega 3 (6), 639-656.

Veer, T., Jell, F., 2012. Contributing to markets for technology? a comparison of patent filing motives of individual inventors, small companies and universities. Technovation 32 (9), 513-522.

Verhoef, P. C., Leeflang, P. S., 2009. Understanding the marketing department's influence within the firm. Journal of Marketing 73 (2), 14-37.

Von Wartburg, I., Teichert, T., Rost, K., 2005. Inventive progress measured by multi-stage patent citation analysis. Research Policy 34 (10), 1591-1607.

Woerter, M., 2012. Technology proximity between firms and universities and technology transfer. The Journal of Technology Transfer 37 (6), 828-866.

Youtie, J., Iacopetta, M., Graham, S., 2008. Assessing the nature of nanotechnology: can we uncover an emerging general purpose technology? The Journal of Technology Transfer 33 (3), 315-329.

Yusuf, S., 2008. Intermediating knowledge exchange between universities and businesses. Research Policy 37 (8), 1167-1174.

Zucker, L., Darby, M., 1996. Star scientists and institutional transformation: Patterns of invention and innovation in the formation of the biotechnology industry. Proceedings of the National Academy of Sciences of the United States of America 93 (23), 12709-12716.

Zucker, L. G., Darby, M. R., Armstrong, J. S., 2002. Commercializing knowledge: 
University science, knowledge capture, and firm performance in biotechnology. Management Science 48 (1), 138-153. 